\title{
Resolution of morphology-based taxonomic delusions: Acrocordiella, Basiseptospora, Blogiascospora, Clypeosphaeria, Hymenopleella, Lepteutypa, Pseudapiospora, Requienella, Seiridium and Strickeria
}

\author{
W.M. Jaklitsch ${ }^{1,2}$, A. Gardiennet ${ }^{3}, H$. Voglmayr ${ }^{2}$
}

\section{Key words}

Ascomycota

Dothideomycetes

new genus

phylogenetic analysis

pyrenomycetes

Pyrenulales

Sordariomycetes

Xylariales

\begin{abstract}
Fresh material, type studies and molecular phylogeny were used to clarify phylogenetic relationships of the nine genera Acrocordiella, Blogiascospora, Clypeosphaeria, Hymenopleella, Lepteutypa, Pseudapiospora, Requienella, Seiridium and Strickeria. At first sight, some of these genera do not seem to have much in common, but all were found to belong to the Xylariales, based on their generic types. Thus, the most peculiar finding is the phylogenetic affinity of the genera Acrocordiella, Requienella and Strickeria, which had been classified in the Dothideomycetes or Eurotiomycetes, to the Xylariales. Acrocordiella and Requienella are closely related but distinct genera of the Requienellaceae. Although their ascospores are similar to those of Lepteutypa, phylogenetic analyses do not reveal a particularly close relationship. The generic type of Lepteutypa, L. fuckelii, belongs to the Amphisphaeriaceae. Lepteutypa sambuci is newly described. Hymenopleella is recognised as phylogenetically distinct from Lepteutypa, and Hymenopleella hippophaëicola is proposed as new name for its generic type, Sphaeria (= Lepteutypa) hippophaës. Clypeosphaeria uniseptata is combined in Lepteutypa. No asexual morphs have been detected in species of Lepteutypa. Pseudomassaria fallax, unrelated to the generic type, $P$. chondrospora, is transferred to the new genus Basiseptospora, the genus $P$ seudapiospora is revived for $P$. corni, and Pseudomassaria carolinensis is combined in Beltraniella (Beltraniaceae). The family Clypeosphaeriaceae is discontinued, because the generic type of Clypeosphaeria, C. mamillana, is a member of the Xylariaceae. The genus Seiridium, of which the sexual morph Blogiascospora is confirmed, is unrelated to Lepteutypa, as is Lepteutypa cupressi. The taxonomy of the cypress canker agents is discussed. The family Sporocadaceae is revived for a large clade of the Xylariales that contains Hymenopleella, Seiridium and Strickeria among a number of other genera. Neotypes are proposed for Massaria fuckelii and Sphaeria hippophaës. Didymella vexata, Seiridium marginatum, Sphaeria corni, Sphaeria hippophaës, Sphaeria seminuda are epitypified, Apiosporina fallax, Massaria occulta, Sphaeria mamillana and Strickeria kochii are lecto- and epitypified. We also provide DNA data for Broomella vitalbae, Cainia desmazieri and Creosphaeria sassafras.
\end{abstract}

Article info Received: 19 August 2015; Accepted: 11 November 2015; Published: 13 January 2016.

\section{INTRODUCTION}

The starting point of this work was the collection of a fungus in Northern England during the BMS Ascomycete workshop in May 2011. This fungus was initially identified as Requienella seminuda. Later collections of true Requienella spp. from Fraxinus in Scandinavia and Olea in Crete, however, showed that the fungus from England on Sambucus is not congeneric with Requienella but with Lepteutypa and is thus described as the new species Lepteutypa sambuci below. To determine this relationship, the type species of Lepteutypa, L. fuckelii, was recollected and sequenced. Seiridium has been claimed to be the asexual morph of Lepteutypa (implemented in Index Fungorum) and the latter was proposed to be synonymised under Seiridium in a nomenclatural session at the IMC10 in Bangkok based on the sexual-asexual connection implemented in Index Fungorum, although the relationship was not based on the generic types of Lepteutypa and Seiridium. Therefore the generic type of

${ }^{1}$ Institute of Forest Entomology, Forest Pathology and Forest Protection, Dept. of Forest and Soil Sciences, BOKU-University of Natural Resources and Life Sciences, Hasenauerstraße 38, 1190 Vienna, Austria.

2 Division of Systematic and Evolutionary Botany, Department of Botany and Biodiversity Research, University of Vienna, Rennweg 14, 1030 Vienna, Austria; corresponding author e-mail: walter.jaklitsch@univie.ac.at.

314 rue Roulette, F-21260 Véronnes, France.
Seiridium, S. marginatum and its Blogiascospora sexual morph were recollected and sequenced. Acrocordiella was included in the study in order to assess its relationship to Requienella, of which it was treated as a synonym. The Requienellaceae are here determined as a family of the Xylariales. Last but not least, Strickeria was included, because it had been used for species of Dothideomycetes, but turned out to belong to the Xylariales in this study. The history of taxonomic treatments is given for each genus in the Taxonomy section. This work is a continuation of Jaklitsch \& Voglmayr (2012), who determined the phylogenetic affiliations of five genera of the Xylariales. Additional data and phylogenetic evidence allow us also to reclassify species of Pseudomassaria, which are not congeneric with the generic type, $P$. chondrospora. During manuscript preparation the phylogenetic treatment of the Xylariomycetidae by Senanayake et al. (2015) became available, which finally called for inclusion of Clypeosphaeria mamillana and Pseudapiospora (Pseudomassaria) corni in this work.

\section{MATERIALS AND METHODS}

\section{Isolates and specimens}

All isolates used in this study originated from ascospores or conidia of fresh specimens. Numbers of strains including 
Table 1 Isolates and accession numbers used in the phylogenetic analyses. Isolates/sequences in bold were isolated/sequenced in the present study.

\begin{tabular}{|c|c|c|c|c|c|c|c|}
\hline \multirow[t]{2}{*}{ Taxon } & \multirow[t]{2}{*}{ Strain } & \multicolumn{2}{|c|}{ GenBank accessions } & \multirow[t]{2}{*}{ Taxon } & \multirow[t]{2}{*}{ Strain } & \multicolumn{2}{|c|}{ GenBank accessions } \\
\hline & & ITS & LSU & & & ITS & LSU \\
\hline \multirow[t]{2}{*}{ Acrocordiella occulta } & RS9 & КT949893 & КT949893 & Leiosphaerella praeclara & CBS 125586 & JF440976 & JF440976 \\
\hline & RS10 & КT949894 & КT949894 & Lepteutypa cupressi & IMI 052255 & AF009817 & AF382379 \\
\hline Adisciso tricellulare & NBRC 32705 & AB594796 & AB593728 & Lepteutypa fuckelii & LEF = CBS 140409 & KT949902 & KT949902 \\
\hline Adisciso yakushimense & HHUF 29671 & AB594789 & AB593721 & & LEF1 & КT949903 & КT949903 \\
\hline Alnecium auctum & CBS 124263 & - & KF570154 & Lepteutypa sambuci & RS = CBS 131707 & КT949904 & КT949904 \\
\hline Amphibambusa bambusicola & MFLUCC 11-0617 & KP744433 & KP744474 & & RS5 & КT949905 & КT949905 \\
\hline Amphisphaeria sorbi & MFLUCC 13-0721 & KR092797 & KP744475 & & RS6 & KT949906 & KT949906 \\
\hline Amphisphaeria umbrina & HKUCC 994 & AF009805 & AF452029 & Lopadostoma dryophilum & CBS 133213 & KC774570 & KC774570 \\
\hline Anthostoma decipiens & $\mathrm{CD}=\mathrm{CBS} 133221$ & KC774565 & KC774565 & Lopadostoma gastrinum & CBS 134632 & KC774584 & KC774584 \\
\hline Anthostomella brabeji & CBS 110128 & EU552098 & EU552098 & Lopadostoma turgidum & CBS 133207 & KC774618 & KC774618 \\
\hline Anthostomella eucalyptorum & CBS 120036 & DQ890026 & DQ890026 & Melanconis stilbostoma & CBS 121894 & - & JQ926229 \\
\hline Apiospora bambusae & ICMP 6889 & - & DQ368630 & Melogramma campylosporum & MBU & JF440978 & JF440978 \\
\hline Apiospora setosa & ICMP 4207 & - & DQ368631 & Microdochium lycopodinum & CBS 122885 & JF440979 & JF440979 \\
\hline Arecophila bambusae & HKUCC 4794 & - & AF452038 & Microdochium phragmitis & CBS 285.71 & AJ279449 & EU926218 \\
\hline Arthrinium phragmites & CBS 135458 & KF144909 & KF144956 & Monochaetia kansensis & PSHI2004Endo1030 & DQ534044 & DQ534035 \\
\hline Arthrinium saccharicola & CBS 831.71 & KF144922 & KF144969 & Monochaetia monochaeta & CBS 199.82 & - & AF382370 \\
\hline Atrotorquata lineata & HKUCC 3263 & AF009807 & - & Morinia pestalozzioides & F-090354 & AY929325 & - \\
\hline Barrmaelia macrospora & BM & KC774566 & KC774566 & Nectria cinnabarina & CBS 125165 & - & HM484562 \\
\hline Bartalinia laurina & HKUCC 6537 & AF405302 & AF382369 & Neopestalotiopsis protearum & CBS 114178 & JN712498 & JN712564 \\
\hline Bartalinia pondoensis & CMW 31067 & GU291796 & GU291796 & Neopestalotiopsis rosae & CBS 101057 & KM199359 & KM116245 \\
\hline Bartalinia robillardoides & CBS 122705 & KJ710460 & KJ710438 & Ophiostoma piliferum & CBS 158.74 & - & DQ470955 \\
\hline Basiseptospora fallax & PSC & JF440983 & JF440983 & Pestalotiopsis knightiae & CBS 114138 & KM199310 & KM116227 \\
\hline Beltrania pseudorhombica & CBS 138003 & KJ869158 & KJ869215 & Pestalotiopsis malayana & CBS 102220 & KM199306 & KM116238 \\
\hline Beltrania rhombica & strain 16.1 & GU797390 & - & Phlogicylindrium eucalyptorum & CBS 111689 & KF251205 & KF251708 \\
\hline \multirow[t]{2}{*}{ Beltraniella carolinensis } & IFO 9502 = & $00950202^{*}$ & DQ810233 & Phlogicylindrium uniforme & CBS 131312 & JQ044426 & JQ044445 \\
\hline & NBRC 9502 & & & Polyancora globosa & CBS 118182 & DQ396469 & DQ396466 \\
\hline Beltraniella endiandrae & CBS 137976 & KJ869128 & KJ869185 & Pseudapiospora corni & PCO = CBS 140736 & КT949907 & КT949907 \\
\hline Beltraniella odinae & NBRC 6774 & $00677401^{*}$ & $00677401^{*}$ & & PCO1 & КT949908 & КT949908 \\
\hline Beltraniella portoricensis & NBRC 9079 & $00907901^{*}$ & 00907901* & Pseudomassaria chondrospora & CBS 125600 & JF440981 & JF440981 \\
\hline Beltraniopsis neolitseae & CBS 137974 & KJ869126 & KJ869183 & Pseudomassaria sepincoli- & & & \\
\hline Biscogniauxia nummularia & MUCL 51395 & JX658444 & KT281894 & formis & CBS 129022 & JF440984 & JF440984 \\
\hline Broomella vitalbae & $\mathrm{BV}=\mathrm{CBS} 140412$ & КT949895 & KT949895 & Pseudomassariella vexata & LVE & JF440977 & JF440977 \\
\hline Cainia desmazieri & CAI & KT949896 & КT949896 & Pseudopestalotiopsis cocos & CBS 272.29 & KM199378 & KM116276 \\
\hline Cainia graminis & CBS 136.62 & KR092793 & AF431949 & Pseudopestalotiopsis theae & MFLUCC 12-0055 & NR_111716 & KM116282 \\
\hline Calosphaeria pulchella & CCTU 316 & - & JX876611 & Repetophragma inflatum & NN 42958 & - & DQ408576 \\
\hline Camillea obularia & ATCC 28093 & AF201714 & - & Requienella fraxini & RS2 & KT949909 & KT949909 \\
\hline Chaetosphaeria innumera & MR 1175 & - & AF178551 & & RS3 & KT949910 & КT949910 \\
\hline Ciliochorella castaneae & HHUF 28799 & - & AB433277 & & RS7 & КT949911 & КT949911 \\
\hline \multirow[t]{3}{*}{ Clypeosphaeria mamillana } & CLM = CBS 140735 & КT949897 & КT949897 & Requienella seminuda & RS12 & KT949912 & KT949912 \\
\hline & CLM1 & КT949898 & КT949898 & & RS13 & Кт949913 & КT949913 \\
\hline & CLM2 & КT949899 & КT949899 & Robillarda africana & CBS 122.75 & KR873253 & KR873281 \\
\hline Clypeosphaeria uniseptata & HKUCC 6349 & - & DQ810219 & Robillarda sessilis & CBS 114312 & KR873256 & KR873284 \\
\hline Collodiscula japonica & CBS 124266 & JF440974 & JF440974 & Sarcostroma restionis & CBS 118154 & DQ278922 & DQ278924 \\
\hline Coniocessia maxima & strain Co117 & GU553332 & GU553344 & Seimatosporium eucalypti & CBS 115131 & JN871200 & JN871209 \\
\hline Coniocessia nodulisporioides & CBS 281.77 & GU553333 & GU553352 & Seimatosporium hypericinum & NBRC 32647 & AB594805 & AB593737 \\
\hline Creosphaeria sassafras & CrS = CBS 127876 & КT949900 & КT949900 & Seimatosporium rosae & MFLUCC 14-0621 & KT198726 & KT198727 \\
\hline Cryptovalsa rabenhorstii & Crel = CBS 125574 & KC774567 & KC774567 & Seiridium cardinale & CBS 172.56 & - & AF382376 \\
\hline Daldinia concentrica & CBS 113277 & AY616683 & KT281895 & Seiridium cupressi & ATCC 48158 & FJ430600 & - \\
\hline Diaporthe eres & CBS 109767 & - & AF408350 & Seiridium marginatum & BLO = CBS 140403 & КT949914 & КT949914 \\
\hline Diatrype disciformis & CBS 197.49 & - & DQ470964 & & SEI & КT949915 & KT949915 \\
\hline Diatrype palmicola & MFLUCC 11-0018 & KP744439 & KP744481 & & SEI1 = CBS 140404 & КT949916 & КT949916 \\
\hline Diatrype whitmanensis & ATCC MYA-4417 & FJ746656 & FJ430587 & Seiridium papillatum & CBS 340.97 & - & DQ414531 \\
\hline Discosia artocreas & NBRC 8975 & AB594773 & AB593705 & Seiridium phylicae & CPC 19965 & KC005787 & KC005809 \\
\hline Discosia pini & MAFF 410149 & AB594776 & AB593708 & Seynesia erumpens & SMH 1291 & - & AF279410 \\
\hline Discostroma tostum & NBRC 32626 & AB594795 & AB593727 & Sporidesmium knawiae & CBS 123529 & FJ349609 & FJ349610 \\
\hline Dyrithiopsis lakefuianensis & HKUCC 7303 & - & AF452047 & Strickeria kochii & C138 & KT949917 & КT949917 \\
\hline Ellurema indica & IMI 136542 & AF009816 & - & & C143 = CBS 140411 & КT949918 & КT949918 \\
\hline Eutypa lata & CBS 208.87 & DQ006927 & - & & C146 & КT949919 & КT949919 \\
\hline Funiliomyces biseptatus & CBS 100373 & - & AY772015 & & C149 & KT949920 & KT949920 \\
\hline Graphostroma platystoma & CBS 270.87 & JX658535 & AY083827 & Stromatonectria caraganae & CBS 125579 & - & HQ112288 \\
\hline Hymenopleella hippo- & & & & Truncatella angustata & ICMP 7062 & AF405306 & AF382383 \\
\hline phaëicola & $\mathrm{LH}=\mathrm{CBS} 140410$ & КT949901 & КT949901 & Truncatella hartigii & CBS 118148 & DQ278913 & DQ278928 \\
\hline Hyponectria buxi & UME 31430 & - & AY083834 & Truncatella restionacearum & CMW 18755 & DQ278915 & DQ278929 \\
\hline Hypoxylon fragiforme & MUCL 51264 & KC477229 & - & Vialaea mangifia & MFLUCC 12-0808 & KF724974 & KF724975 \\
\hline Idriella lunata & MUCL 7551 & KC775735 & KC775710 & Vialaea minutella & BRIP 56959 & KC181926 & KC181924 \\
\hline Immersidiscosia eucalypti & MAFF 242781 & AB594793 & AB593725 & Xylaria hypoxylon & CBS 122620 & AM993141 & - \\
\hline Kretzschmaria deusta & CBS 163.93 & KC477237 & KT281896 & Xylaria polymorpha & MUCL_49904 & FN689809 & KT281899 \\
\hline Leiosphaerella lycopodina & CBS 125717 & JF440975 & JF440975 & Zetiasplozna acaciae & CBS 137994 & KJ869149 & KJ869206 \\
\hline
\end{tabular}

* Sequence downloaded from the Biological Resource Center (NBRC), NITE, Japan (http://www.nbrc.nite.go.jp/) 
$\mathrm{NCBI}$ GenBank accession numbers of gene sequences used to compute the phylogenetic trees are listed in Table 1. Strain acronyms other than those of official culture collections are used here primarily as strain identifiers throughout the work. Representative isolates have been deposited at the CBS-KNAW Fungal Biodiversity Centre, Utrecht, The Netherlands (CBS). Details of the specimens used for morphological investigations are listed in the Taxonomy section under the respective descriptions. Herbarium acronyms are according to Thiers (2015), abbreviations of exsiccata according to Triebel \& Scholz (2015). Freshly collected specimens have been deposited in the Herbarium of the Institute of Botany, University of Vienna (WU).

\section{Culture preparation, growth rate determination and phenotype analysis}

Cultures were prepared and maintained as described previously (Jaklitsch 2009) except that CMD (CMA: Sigma, St Louis, Missouri; supplemented with $2 \%(\mathrm{w} / \mathrm{v}) \mathrm{D}(+)$-glucosemonohydrate) or $2 \%$ malt extract agar (MEA; $2 \% \mathrm{w} / \mathrm{v}$ malt extract, $2 \%$ w/v agar-agar; Merck, Darmstadt, Germany) was used as the isolation medium. Cultures used for the study of asexual morph micro-morphology were grown on CMD or $2 \%$ MEA at $22 \pm 3^{\circ} \mathrm{C}$ under alternating $12 \mathrm{~h}$ cool daylight and $12 \mathrm{~h}$ darkness. Microscopic observations were made in tap water except where noted. Morphological analyses of microscopic

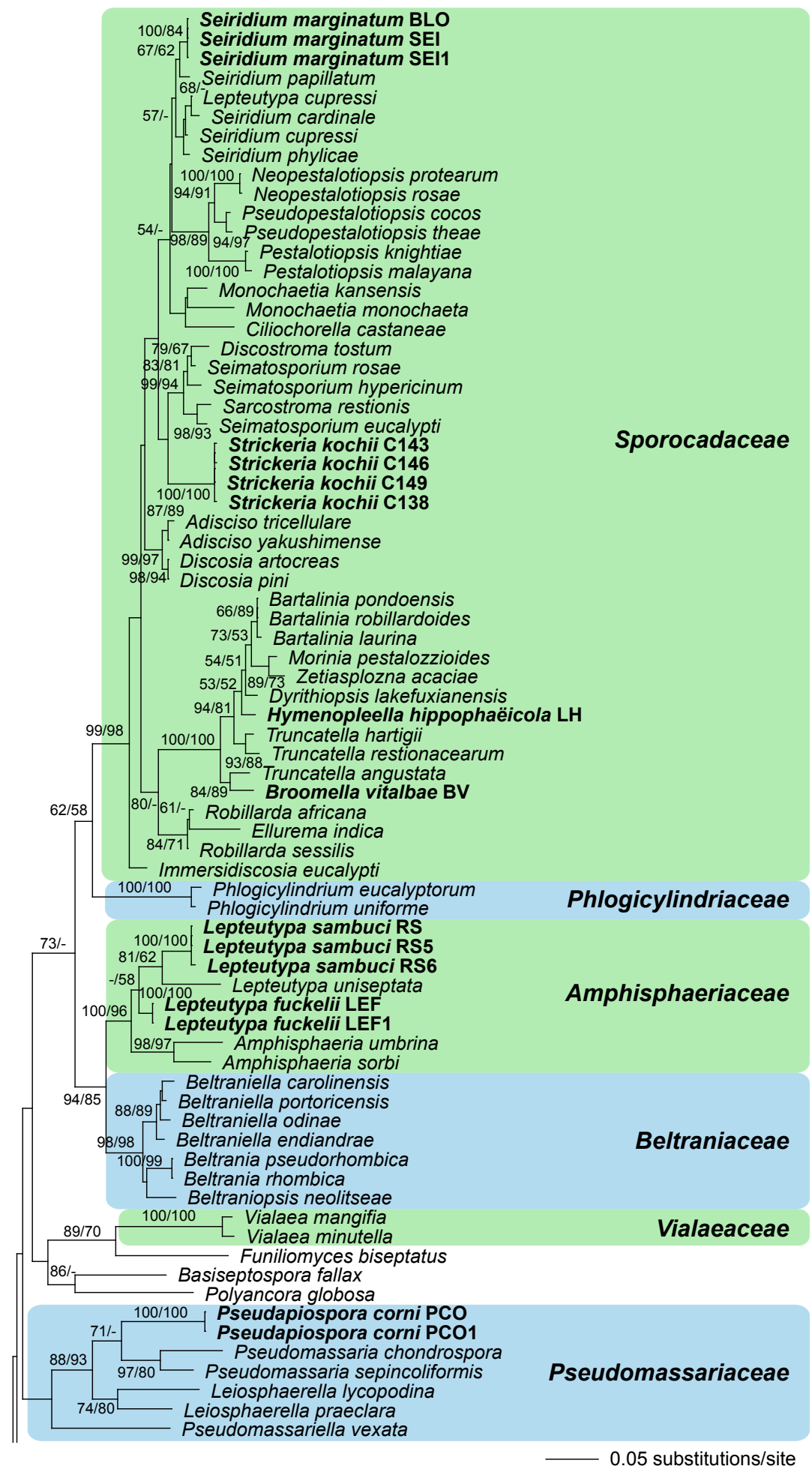

Fig. 1 Phylogram of the best maximum likelihood tree (InL = -19786.9825) revealed by RAxML from an analysis of a representative ITS-LSU rDNA matrix from Xylariales, showing the phylogenetic position of Acrocordiella, Basiseptospora, Blogiascospora, Clypeosphaeria, Hymenopleella, Lepteutypa, Pseudapiospora, Requienella, Seiridium and Strickeria. ML and MP bootstrap support above $50 \%$ are given above or below the branches. The tree was rooted with eight taxa from Sordariomycetes. Taxa in bold were sequenced in the present study. 
characters were carried out as described earlier (Jaklitsch 2009). Methods of microscopy included stereomicroscopy using a Nikon SMZ 1500 and Nomarski differential interference contrast (DIC) using the compound microscopes Nikon Eclipse E600 and Zeiss Axio Imager A1 microscope equipped with a Zeiss Axiocam 506 colour digital camera. Images and data were gathered using a Nikon Coolpix 4500 or a Nikon DS-U2 digital camera and measured by using the NIS-Elements D v. 3.0 or Zeiss ZEN Blue Edition softwares. For certain images of ascomata the stacking software Zerene Stacker v. 1.04 (Zerene Systems LLC, Richland, WA, USA) was used. Measurements are reported as maximum and minimum in parentheses and the mean plus and minus the standard deviation of a number of measurements given in parentheses.

\section{DNA extraction and sequencing methods}

The extraction of genomic DNA was performed as reported previously (Voglmayr \& Jaklitsch 2011, Jaklitsch et al. 2012) using the DNeasy Plant Mini Kit (QIAgen GmbH, Hilden, Germany) or the modified CTAB method of Riethmüller et al. (2002). The following loci were amplified and sequenced: the complete internally transcribed spacer region (ITS1-5.8S-ITS2) and a c. $900 \mathrm{bp}$ fragment of the large subunit nuclear ribosomal DNA
(nLSU rDNA), amplified and sequenced as a single fragment with primers V9G (De Hoog \& Gerrits van den Ende 1998) and LR5 (Vilgalys \& Hester 1990); a c. $1.2 \mathrm{~kb}$ fragment of the RNA polymerase II subunit 2 ( $r p b 2)$ with primers fRPB2-5f and fRPB2-7cr (Liu et al. 1999); and a c. $1.3 \mathrm{~kb}$ fragment of the translation elongation factor 1-alpha (tef1) with primers EF1728F (Carbone \& Kohn 1999) and TEF1LLErev (Jaklitsch et al. 2005). PCR products were purified using an enzymatic PCR cleanup (Werle et al. 1994) as described in Voglmayr \& Jaklitsch (2008). DNA was cycle-sequenced using the ABI PRISM Big Dye Terminator Cycle Sequencing Ready Reaction Kit v. 3.1 (Applied Biosystems, Warrington, UK) with the same primers as in PCR and an automated DNA sequencer (3730xI Genetic Analyzer, Applied Biosystems).

\section{Analysis of sequence data}

Due to the poor representation of other gene sequences for $X y$ lariales, only the ITS and LSU rDNA were used for phylogenetic inference. To complement the data matrix, ITS and LSU sequences of a representative selection of Xylariales were downloaded from GenBank; for rooting the tree, LSU sequences of eight taxa of Sordariomycetes were included (Table 1). All alignments were produced with the server version of MAFFT

Fig. 1 (cont.)

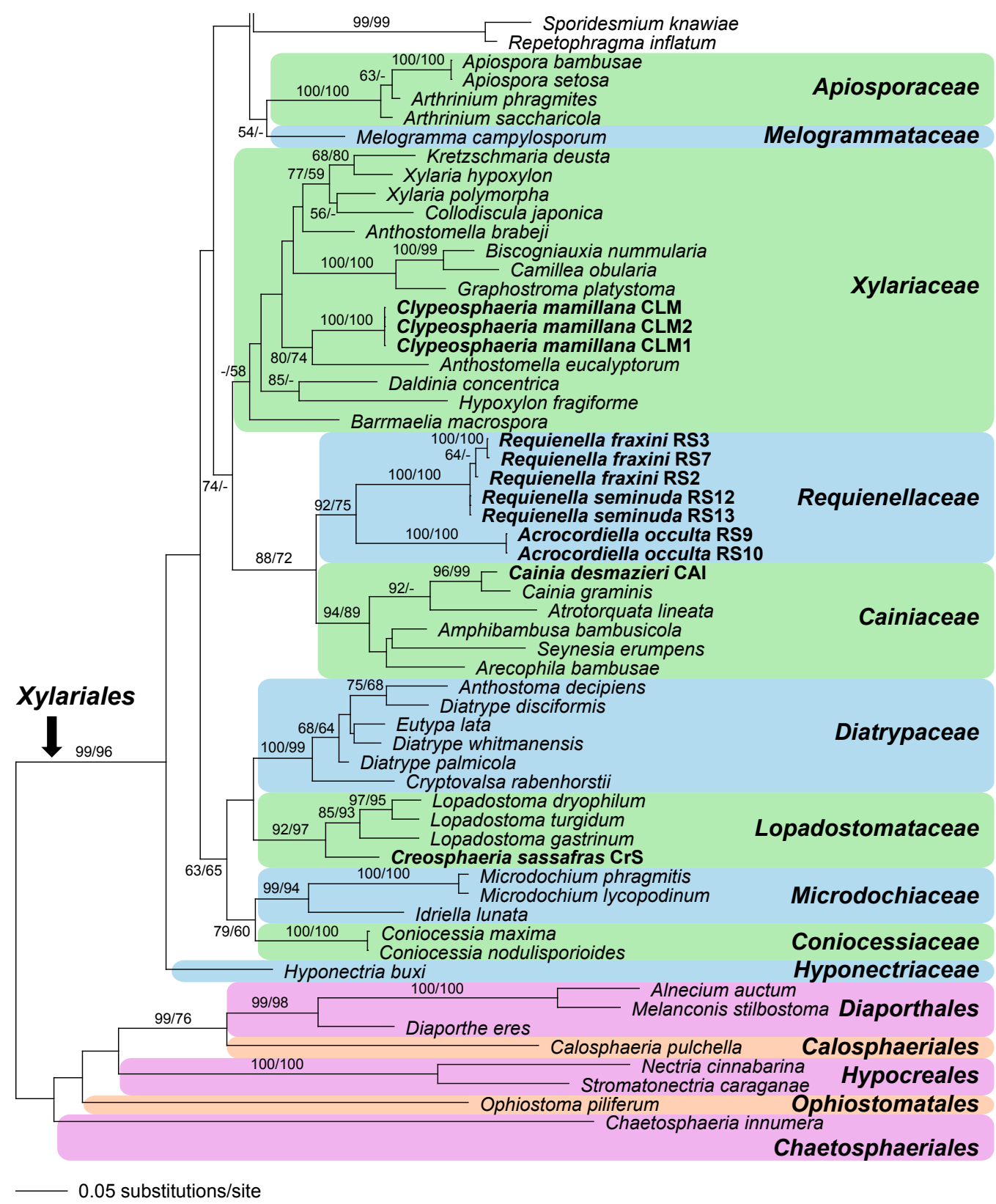


(www.ebi.ac.uk/Tools/mafft), checked and refined using BioEdit v. 7.0.4.1 (Hall 1999). For phylogenetic analyses, the ITS and LSU matrices were combined. After exclusion of poorly aligned regions for the ITS containing large indels, the final matrix contained 518 and 852 nucleotide characters from the ITS and LSU, respectively.

Maximum likelihood (ML) analyses were performed with RAxML (Stamatakis 2006) as implemented in raxmIGUI 1.3 (Silvestro \& Michalak 2012), using the ML + rapid bootstrap setting and the GTRGAMMAI substitution model with 1000 bootstrap replicates. The matrix was partitioned for ITS and LSU, and substitution model parameters were calculated separately for the two regions.

Maximum parsimony (MP) bootstrap analysis of the combined matrix was performed with PAUP v. 4.0a142 (Swofford 2002). All molecular characters were unordered and given equal weight; analyses were performed with gaps treated as missing data; the COLLAPSE command was set to MINBRLEN. $1000 \mathrm{MP}$ bootstrap replicates were performed, with 5 rounds of random sequence addition and subsequent TBR branch swapping (MULTREES option in effect, steepest descent option not in effect), with each replicate limited to 1 million rearrangements.

\section{RESULTS}

\section{Molecular phylogeny}

Of the 1370 characters, 519 were parsimony informative (273 for ITS, 246 for LSU). Fig. 1 shows the phylogram of the best ML tree (InL = -19786.9825) obtained by RAxML. While most families except $X y$ lariaceae received high bootstrap support, the deeper nodes of the tree backbone were mostly unsupported. The genus Lepteutypa was revealed as polyphyletic: while the generic type, L. fuckelii, L. sambuci and Clypeosphaeria (Lepteutypa) uniseptata formed a sister clade to Amphisphaeria within Amphisphaeriaceae, L. hippophaës and L. cupressi were placed within Sporocadaceae in the Bartalinia-Broomella-Truncatella and Seiridium subclades, respectively. Strickeria kochii was placed in the Sporocadaceae as well, with an unsupported sister group relationship to the Discostroma-Seimatosporium subclade (Fig. 1). The generic type of Seiridium, Seiridium marginatum, was placed within the Seiridium subclade, and sequence data confirmed Blogiascospora marginata as its sexual morph. Acrocordiella and Requienella were revealed as sister genera with medium (MP) to high (ML) support, and their sister group relationship to Cainiaceae received medium (MP) to high (ML) support. Cainia desmazieri was revealed as closely related to the generic type, Cainia graminis. Clypeosphaeria mamillana is shown to be unrelated to Clypeosphaeria (Lepteutypa) uniseptata but closest relative to Anthostomella eucalyptorum within Xylariaceae. Pseudapiospora corni was placed within Pseudomassariaceae as closest relative of Pseudomassaria with medium (ML) or no (MP) support. In agreement with Jaklitsch \& Voglmayr (2012), Pseudomassaria carolinensis and $P$. fallax are not contained within Pseudomassariaceae, the former being placed within Beltraniella (Beltraniaceae) with high support, whereas the latter is closest relative of Polyancora globosa.

\section{Taxonomy}

Families are given in alphabetical order and the treated taxa are presented under each family: Amphisphaeriaceae (Lepteutypa), Beltraniaceae (Beltraniella carolinensis), Pseudomassariaceae (Pseudapiospora, Pseudomassariella), Requienellaceae (Acrocordiella, Requienella), Sporocadaceae (Blogiascospora/Seiridium, Hymenopleella, Strickeria), Xylariaceae (Clypeosphaeria), Xylariales inc. sed. (Basiseptospora).
Amphisphaeriaceae G. Winter 1885

Lepteutypa Petr., Ann. Mycol. 21: 276. 1923

Type species. Lepteutypa fuckelii (G.H. Otth) Petr.

Lepteutypa fuckelii (G.H. Otth) Petr., Ann. Mycol. 21: 276. 1923 - Fig. 2

Basionym. Massaria fuckelii G.H. Otth, Mitth. Naturf. Ges. Bern Nr. 654-683: 50. 1868

= Massaria fuckelii Fuckel, Jahrb. Nassauischen Vereins Naturk. 23-24: 155. 1870. [1869-70].

Typification. Neotype proposed here: BeLgium, Leuven, Heferlee, Heferleebos, on Tilia cordata, soc. Amphisphaeria multipunctata, 31 May 2012, P. Bormans (WU 33554; MBT202953; ex-neotype culture LEF = CBS 140409).

Perithecia immersed in sometimes slightly uneven bark, only visible as minute dark dots, sometimes surrounded by grey clypei $0.3-0.6 \mathrm{~mm}$ diam on the otherwise unaltered, lightcoloured bark surface, scattered or aggregated in small groups, depressed globose, dark, (0.25-)0.45-0.57(-0.6) mm diam, 0.2-0.4 mm high; peridium 20-40 $\mu \mathrm{m}$ thick, brown, hyaline inside, pseudoparenchymatous. Ostioles inconspicuous to blunt papillate and shiny black, 80-150 $\mu \mathrm{m}$ diam, sometimes region around ostiole slightly darker and depressed; sometimes whitish to greyish brown mycelium present around perithecia. Apically free paraphyses 2-6 $\mu \mathrm{m}$ wide, simple, multiguttulate. Asci $(107-) 111-155(-185) \times(9.8-) 10.5-13.3(-14.5) \mu \mathrm{m}(\mathrm{n}=20)$, cylindrical, with 8 uniseriate ascospores, with a short stipe, croziers and a thickened apex containing a thin amyloid apical ring, (3.0-)3.2-4.2(-4.5) $\mu \mathrm{m}$ wide and (0.7-)0.8-1.2(-1.4) $\mu \mathrm{m}$ high $(\mathrm{n}=20)$. Ascospores $(15.5-) 17.5-22.8(-29.7) \times(5.7-)$ $6.5-8.0(-8.7) \mu \mathrm{m}, \mathrm{I} / \mathrm{w}(2.0-) 2.4-3.2(-4.2)(\mathrm{n}=114)$, oblong or narrowly fusiform, first hyaline, turning yellow to yellow-brown, with 1 median, slightly constricted euseptum and 2 distosepta, straight to slightly curved, multiguttulate when vital, hyaline to yellowish and with a narrow mucous sheath (e.g. $1.5 \mu \mathrm{m}$ wide) or polar caps in the ascus when young, turning olive-green in Lugol, with 1 guttule per cell, massaria-like, i.e. with a dramatic difference between the living and dead state.

Culture characteristics - Growth radius after 1 mo at room temperature on CMD up to c. $25 \mathrm{~mm}$, on MEA to c. $32 \mathrm{~mm}$; colony circular, sometimes finely zonate, white, becoming brown, olive to nearly black from the centre, odour indistinct. No asexual morph observed.

Habitat - In bark of Tilia spp.

Distribution - Europe.

Additional material examined. Germany, Nordrhein-Westfalen, Schlosspark Türnich at Kerpen, MTB 5106/142, 4 Mar. 2013, on attached branches of Tilia cordata, B. Wergen (WU 33555; culture LEF1); Rheingau, on Tilia, L. Fuckel, det. Th. Nitschke (B700009241); near Kiedrich, on Tilia, in spring, L. Fuckel, Fungi Rhen. Exs. 1769 (B700009240, G00127792); Oestrich, at Schloß Reichartshausen, on Tilia, in the winter, L. Fuckel (Nassau's flora, G00127791).

Notes - Lepteutypa fuckelii is an uncommon fungus. Agood description of the species can be found in Petrak (1923). He interpreted perithecial colonies as eutypoid stromata forming small irregular spots, but noted that stromatic tissue is only comprised by subhyaline to brownish hyphae. Aberrant ascospores may contain 5 septa with sizes up to $35 \times 10 \mu \mathrm{m}$. No asexual morph has been found for this species.

Nomenclatural background: Nitschke created the name Massaria fuckelii, but did not publish it. However, he corresponded with both Otth and Fuckel about the fungus, who collected their own materials and independently described the fungus. Otth (1868) was first, i.e. Fuckel's Massaria fuckelii is a heterotypic 

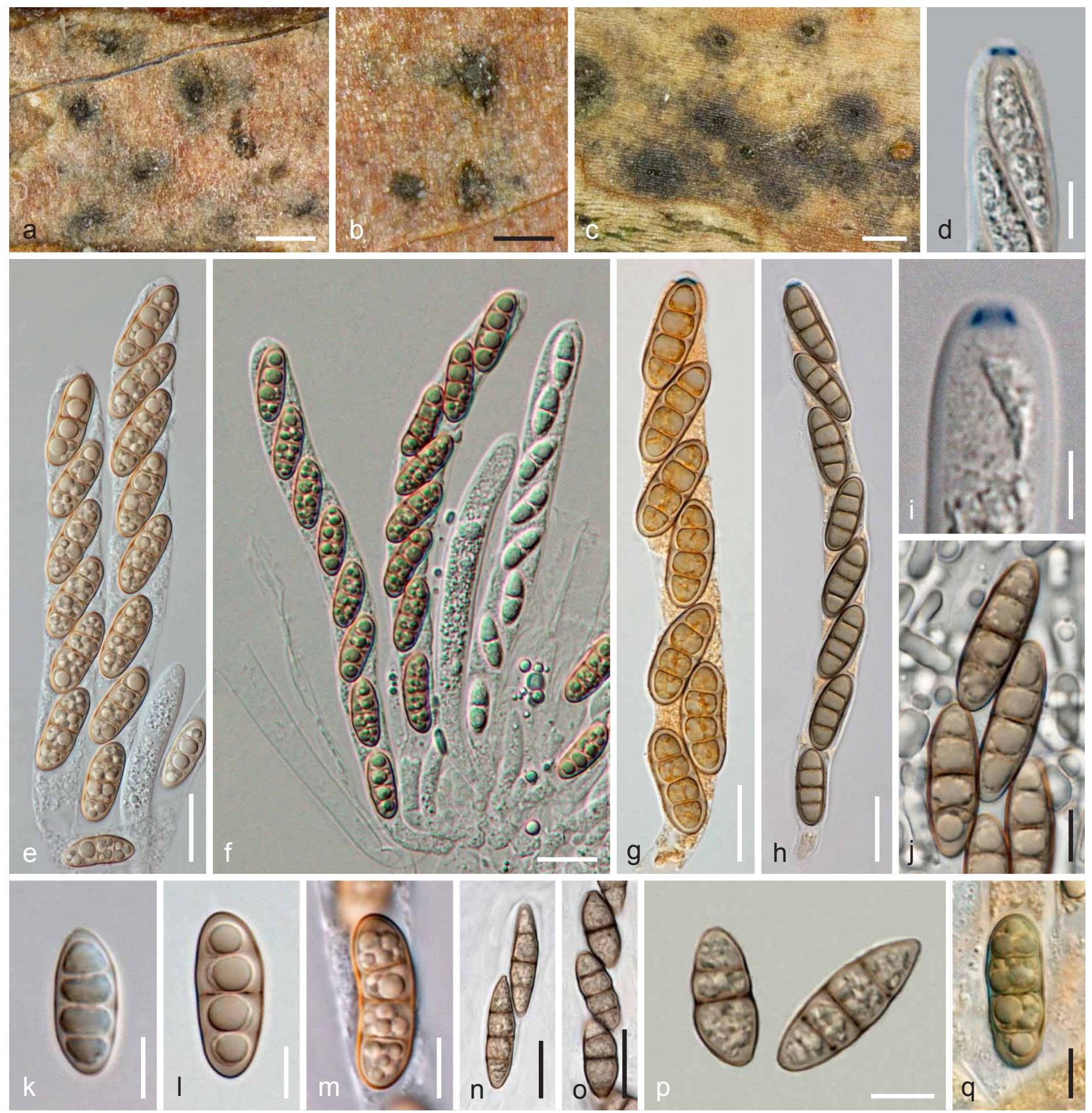

Fig. 2 Lepteutypa fuckelii. a-c. Ostioles and clypei on the bark surface; d, i. ascus apices in Lugol; e-h. asci (g, h. in Lugol); $j-q$. ascospores (I, $n-p$. in $3 \%$ KOH; q. in Lugol) (a, b, j, k: WU 33555; c, e-h, I, m, q: WU 33554; d, i, n: G00127792; o: B700009240; p: G00127791). - Scale bars: a, c=0.4 mm; b=0.2 $\mathrm{mm} ; \mathrm{d}, \mathrm{j}-\mathrm{m}, \mathrm{p}, \mathrm{q}=7 \mu \mathrm{m} ; \mathrm{e}-\mathrm{h}, \mathrm{n}, \mathrm{o}=15 \mu \mathrm{m} ; \mathrm{i}=5 \mu \mathrm{m}$.

homonym. Both authors cited Nitschke as the author in order to honour him as the creator of the name, but Nitschke did not provide the descriptions. Nitschke's impact could be honoured as author citations Nitschke ex Otth and Nitschke ex Fuckel, which, however, is not necessary. Specimens of Massaria fuckelii Fuckel collected by Fuckel, which are extant in B and G and labelled Typus, are not type specimens of Massaria fuckelii G.H. Otth. As there is no type material of G.H. Otth available, we propose a neotype here.

Lepteutypa hederae (Fuckel) Rappaz, Mycol. Helv. 7: 160. 1995 - Fig. 3

Basionym. Amphisphaeria hederae Fuckel, Jahrb. Nassauischen Vereins Naturk. 25-26: 304. 1871.

इ Anthostoma hederae (Fuckel) Sacc., Syll. Fung. (Abellini) 1: 301. 1882.

Holotype. SwITZERLAND, near Neuchatel, on dead, corticated branches of Hedera helix, by xylotomy probably Viburnum sp., Mar. 1867, P. Morthier (G00111726!; Herbier Fuckel 1894 ex Herb. Barbey-Boissier, as Amphisphaeria hederae and Anthostoma hederae on the label)
Perithecia immersed in bark and wood beneath black clypei being distinct in wood but diffuse in bark in surface view, flat, convex to pulvinate, $0.7-1.2 \mathrm{~mm}$ diam, $80-160 \mu \mathrm{m}$ thick; perithecia globose, $0.35-0.7 \mathrm{~mm}$ diam, 0.25-0.6 $\mathrm{mm}$ high; peridium brown, pseudoparenchymatous. Paraphyses numerous, simple. Asci oblong, containing 8 uniseriate ascospores, unitunicate but thick-walled, apex not containing a ring, inamyloid, not staining with Congo Red, a diffuse pulvillus turning blue in Cotton Blue (in water); stipe short. Ascospores (19.5-)22-29.2(-35.3) $\times(7.0-) 9.2-12.2(-14) \mu \mathrm{m}, \mathrm{I} / \mathrm{w}(1.6-) 1.8-3.1(-4.6)(\mathrm{n}=40)$, ellipsoid, ovoid to oblong, usually inequilateral with pointed ends, 3-distoseptate, first hyaline, turning brown, indistinctly striate, appearing warted in section.

Habitat - In bark and wood of ? Viburnum sp.

Distribution - Switzerland, only known from the holotype.

Notes - See under Lepteutypa sambuci for a comparison of $L$. hederae with that species. The generic affiliation of $L$. hederae is still unverified, as no fresh material and sequence data are available. 

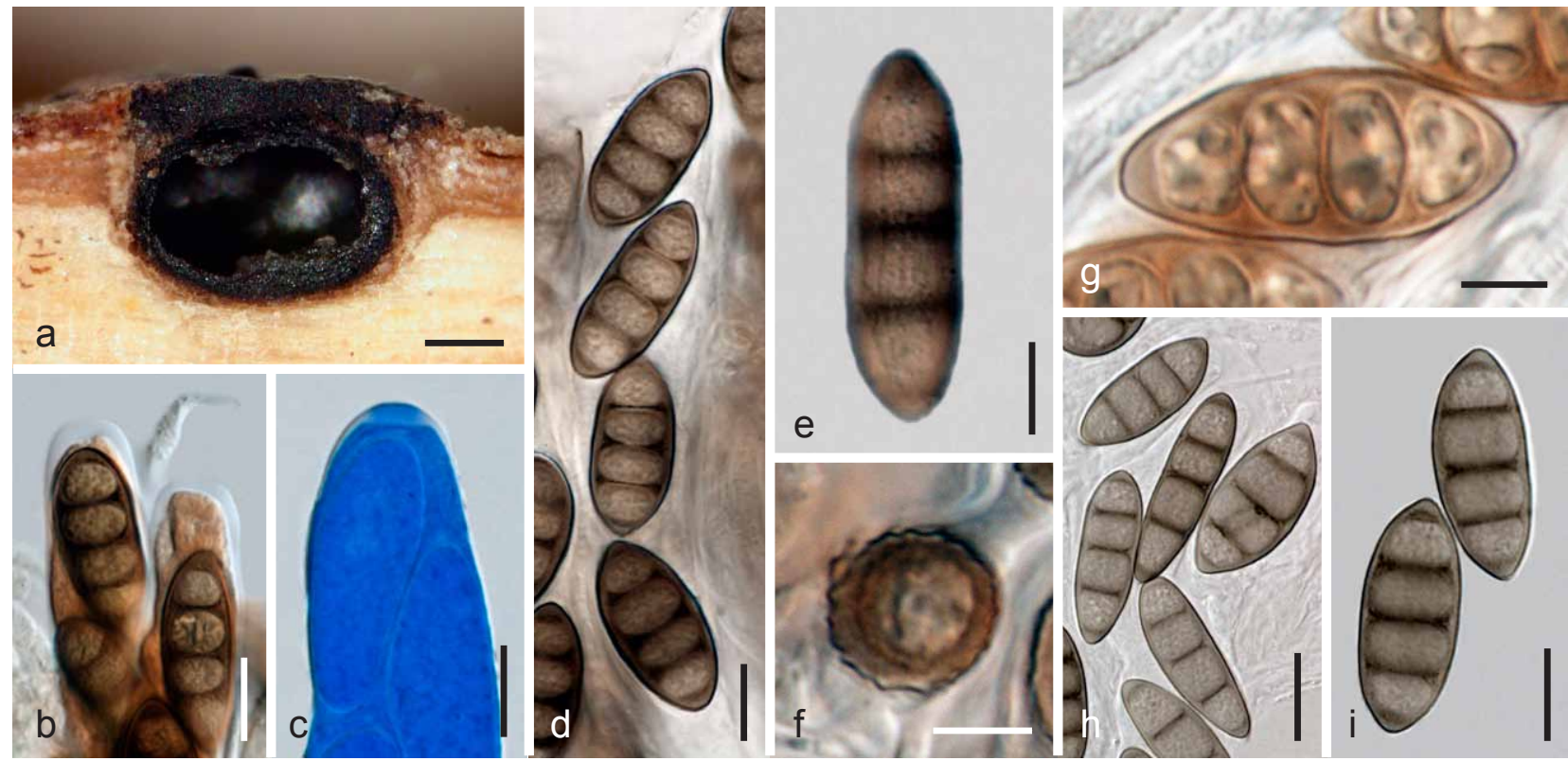

Fig. 3 Lepteutypa hederae (G00111726). a. Ascoma and clypeus in vertical section; b, c. ascus apices (b. in Lugol; c. in aqueous cotton blue); d-i. ascospores (e, f. showing ridges; f. in transverse optical section; $h$, i. in $3 \% \mathrm{KOH}$ ). - Scale bars: $a=0.2 \mathrm{~mm} ; \mathrm{b}-\mathrm{d}, \mathrm{i}=10 \mu \mathrm{m} ; \mathrm{e}=7 \mu \mathrm{m} ; \mathrm{f}, \mathrm{g}=5 \mu \mathrm{m} ; \mathrm{h}=15 \mu \mathrm{m}$.

Lepteutypa sambuci Jaklitsch \& Voglmayr, sp. nov. - MycoBank MB814827; Fig. 4

\section{Etymology. Referring to its occurrence on Sambucus.}

Holotype. England, Yorkshire, Worksop, Rotherham, Anston, Anstonstones Wood, on partly decorticated branches of Sambucus nigra, 16 May 2011, T. Læssøe et al. (WU 33556, culture RS = CBS 131707).

Pseudostromata erumpent from wood, eutypoid, very variable in shape and size, roundish to longish, extending from a few $\mathrm{mm}$ to several $\mathrm{cm}$, covered by a grey to black, $20-80 \mu \mathrm{m}$ thick ectostromatic zone, containing indistinct to white prosenchymatous entostroma and one to numerous perithecia; on bark only visible as minute circular ostiolar discs $50-180 \mu \mathrm{m}$ diam, with umbilicate perforation, sometimes surrounded by some clypeate ectostroma. Ascomata immersed in wood, depressed globose, 0.4-0.8 mm diam, $0.25-0.5 \mathrm{~mm}$ high; peridium consisting of a dark brown, 15-40 $\mu \mathrm{m}$ thick pseudoparenchymatous outer layer and a narrow hyaline to yellowish hyphal inner layer. Paraphyses apically free, simple, $3-4 \mu \mathrm{m}$ wide, attenuated to pointed at the apices. Asci (166-)175-228(-241) × (11.5-) $12.3-16.8(-21.5) \mu m(n=20)$, cylindrical, with short stipe, thick-walled, appearing bitunicate and sometimes fissitunicate, containing (4-)8 uniseriate ascospores, apex thickened, with a small but distinct ocular chamber and a minute thin amyloid subapical ring (3.2-)3.3-4.1(-4.3) $\mu \mathrm{m}$ wide, (0.4-)0.5-0.9 $(-1.2) \mu \mathrm{m}$ high $(\mathrm{n}=24)$, turning pinkish in Congo Red and blue in Waterman black ink. Ascospores (21-)24.5-31.3(-35.7) $\times$ (8.3-)9.0-11.2(-13.5) $\mu \mathrm{m}, \mathrm{I} / \mathrm{w}(2.1-) 2.4-3.1(-4)(\mathrm{n}=117)$, oblong to ellipsoid, straight, rarely curved, light to yellow- or medium brown, with a central scarcely constricted euseptum and 2-4(-6) distosepta, i.e. 3-5(-7)-distoseptate, thick-walled, multiguttulate, when young with a thick sheath or small hyaline terminal caps visible in water and India ink but not stained by Waterman black ink nor aqueous nigrosin; sides sometimes pinched; occasionally with an oblique longitudinal septum; turning olive, sometimes with yellow contents in Lugol.

Culture characteristics - Growth on CMD and MEA slow, colony radius $27-37 \mathrm{~mm}$ after $1 \mathrm{mo}$ at $20^{\circ} \mathrm{C}$; colony white, turning yellow-brown to black from the centre, odour lacking.

Ecology - On mostly decorticated branches of Sambucus nigra lying on the ground, sometimes submerged in aquatic habitats.

Distribution - Europe (England, France, Germany).
Additional material examined. ENGLAND, Buckinghamshire, High Wycombe Hughenden Manor grounds (National Trust), grid reference SU 860 955, on Sambucus nigra, 30 Mar. 2013, P. Thompson (WU 33557, culture RS5); East Cornwall, between Liskeard and Callington, Gang, UK grid reference SX307681 (N50²9'17" W4 $\left.{ }^{\circ} 23^{\prime} 17^{\prime \prime}\right)$, on Sambucus nigra, 9 Mar. 2013, K. PrestonMafham, comm. P. Cannon. - France, Ariège, Castelnau-Durban, Artillac stream, down-stream from the marble quarry, elev. $410 \mathrm{~m}$, on a submerged decorticated branch of Sambucus nigra, 17 Aug. 2015, J. Fournier JF15060; Rimont, La Maille, elev. $550 \mathrm{~m}$, on a submerged decorticated branch of Sambucus nigra, soc. Melanomma fuscidulum, Aquaticola spp., 2 Apr. 2013, J. Fournier JF13064 (WU 33558, culture RS6); same area, La Maille brook, elev. $550 \mathrm{~m}$, submerged decorticated branch of Sambucus nigra, 2 Oct. 2013, J. Fournier JF13177. - Germany, Mecklenburg-Vorpommern, Westmecklenburg, S from Rehna, forest 'Benziner Tannen', on Sambucus nigra, 15 July 2012, T. Richter, comm. H.-O. Baral and G. Friebes (WU 33559).

Notes - Unlike Lepteutypa fuckelii, where perithecia are immersed in bark, $L$. sambuci forms its ascomata immersed in the wood, resembling in this respect $L$. hederae, which differs by consistently 3-septate ascospores lacking a median euseptum and by inamyloid ascus apices.

Lepteutypa uniseptata (K.M. Tsui et al.) Jaklitsch \& Voglmayr, comb. nov. - MycoBank MB814830

Basionym. Clypeosphaeria uniseptata K.M. Tsui et al., Mycologia 93: 1004. 2001.

Notes - All morphological criteria of L. uniseptata used in the protologue to justify its affiliation to the genus Clypeosphaeria such as the presence of a clypeus, long cylindrical asci with subapical, amyloid rings and uniseriate, ellipsoidal, brown ascospores fit to Lepteutypa, which was not considered. Particularly differences from the generic type Clypeosphaeria mamillana, such as a discoid apical ring in C. uniseptata (vs wedge-shaped in C. mamillana), thick-walled ascospores in C. uniseptata, but also the absence of an asexual morph are all typical of Lepteutypa. The shape or structure of the apical discharge apparatus in the ascus appears to be genus-specific in certain groups of the Xylariales (see e.g. Jaklitsch et al. 2014). Thus, the only difference to other species of Lepteutypa is ascospore septation, which can be regarded as negligible when considering the variable septation among other species of Lepteutypa and the clear phylogenetic affiliation of $L$. uniseptata to L. fuckelii. 


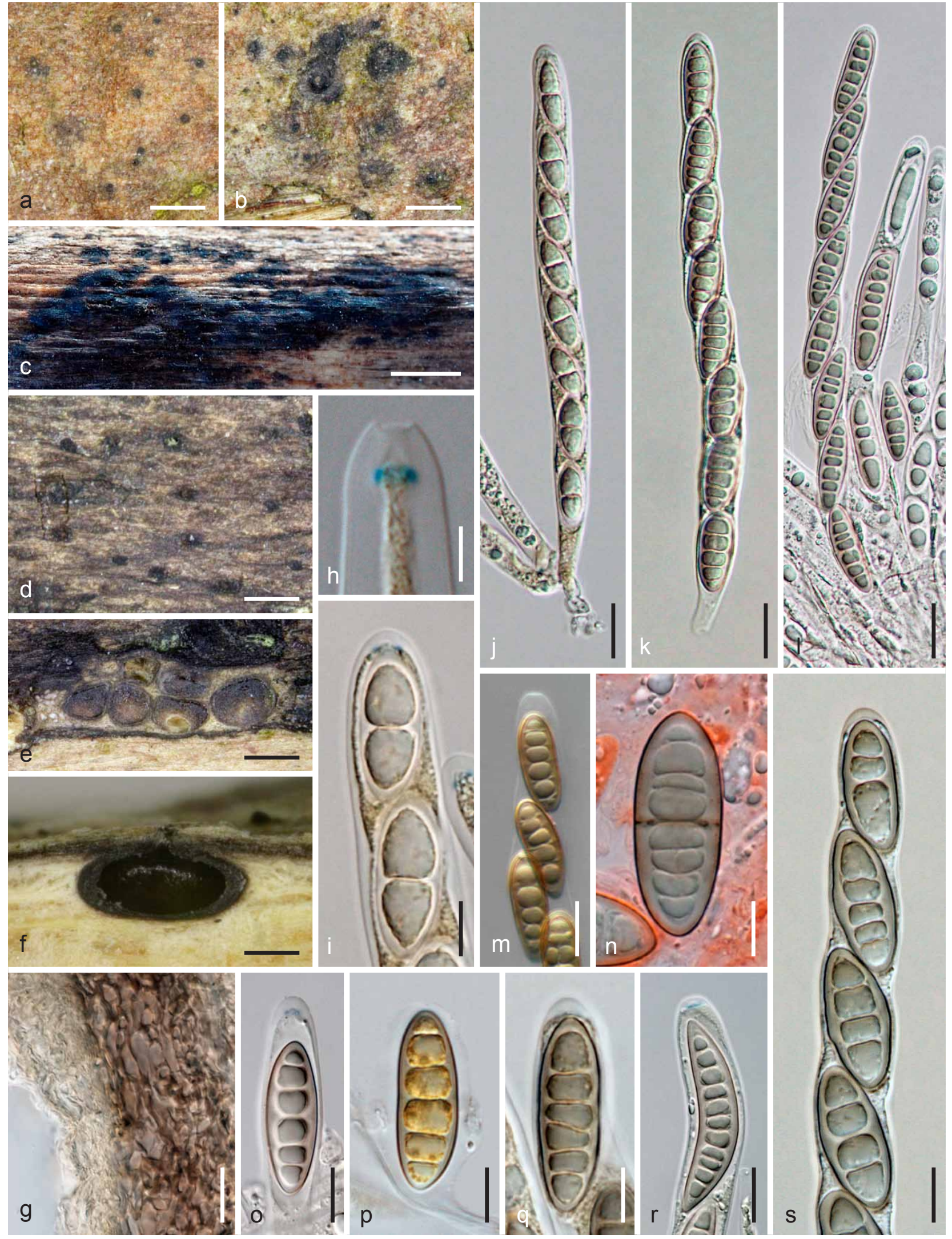

Fig. 4 Lepteutypa sambuci. a, b. Ostioles and clypei on the bark surface; c, d. stromata in face view in wood; e. stroma and ascomata in transverse section; f. ascoma in vertical section; g. ascomatal wall in section; h, i, m, s. ascus apices (h, i, s. in Lugol; h, i. immature); j-l. asci (j. immature, in Lugol; l. in 3 \% $\mathrm{KOH}$ ); n-r. ascospores (n. in Congo Red; o, r. in Lugol/KOH; p, q. in Lugol) (a, b, g, n: WU 33556 RS; c, h, p: WU 33559 (c. image by T. Richter); d, e, I, o, r: WU 33558; f, i-k, q, s: WU 33557; m: East Cornwall (k. image by P. Cannon)). — Scale bars: a, b, d, e = $0.5 \mathrm{~mm} ; \mathrm{c}=2 \mathrm{~mm} ; \mathrm{f}=0.2 \mathrm{~mm} ; \mathrm{g}$, j-m, $\mathrm{r}=15 \mu \mathrm{m}$; $\mathrm{h}=3 \mu \mathrm{m} ; \mathrm{i}, \mathrm{n}, \mathrm{p}, \mathrm{q}=7 \mu \mathrm{m} ; \mathrm{o}, \mathrm{s}=10 \mu \mathrm{m}$. 


\section{Beltraniaceae Nann. 1934}

Beltraniella carolinensis (M.E. Barr \& Hodges) Jaklitsch \& Voglmayr, comb. nov. - MycoBank MB814945

Basionym. Pseudomassaria carolinensis M.E. Barr \& Hodges, Mycologia 63: 562. 1971.

Notes - Pseudomassaria carolinensis is phylogenetically distinct from $P$. chondrospora but contained within the highly supported Beltraniella clade (Fig. 1, as Beltraniella carolinensis). Hodges \& Barr (1971) obtained a Beltraniella asexual morph in pure cultures of $P$ seudomassaria carolinensis, which they tentatively attributed to $B$. portoricensis (F. Stevens) Piroz. \& S.D. Patil. However, they already raised serious doubts about conspecificity due to numerous differences, i.e. smooth setae (verrucose in B. portoricensis; see also key in Castañeda Ruiz et al. 1996); frequent production of ascomata in nature as well as pure cultures (unknown in B. portoricensis and any other Beltraniella species); high host specificity, being constantly associated with ascomata of Phyllachora perseae in circular necrotic spots on living or recently shed leaves of Persea borboni (B. portoricensis being a common leaf litter fungus with low host specificity, widespread in tropical to mild temperate areas); and culture characteristics distinctly different from isolates of $B$. portoricensis obtained from leaf litter. Only an LSU but no ITS sequence is deposited for $P$. carolinensis at GenBank, but at the NBRC (Biological Resource Center, NITE, Japan, http://www.nbrc.nite.go.jp/) an ITS sequence is available for the authentic (likely ex-type) strain IFO 9502 (= NBRC 9502). This ITS sequence differs from all available sequences of B. portoricensis deposited at GenBank (GU905993, KJ512150) and NBRC. Considering the molecular, morphological as well as ecological differences, Pseudomassaria carolinensis is considered a distinct species and here combined in Beltraniella.
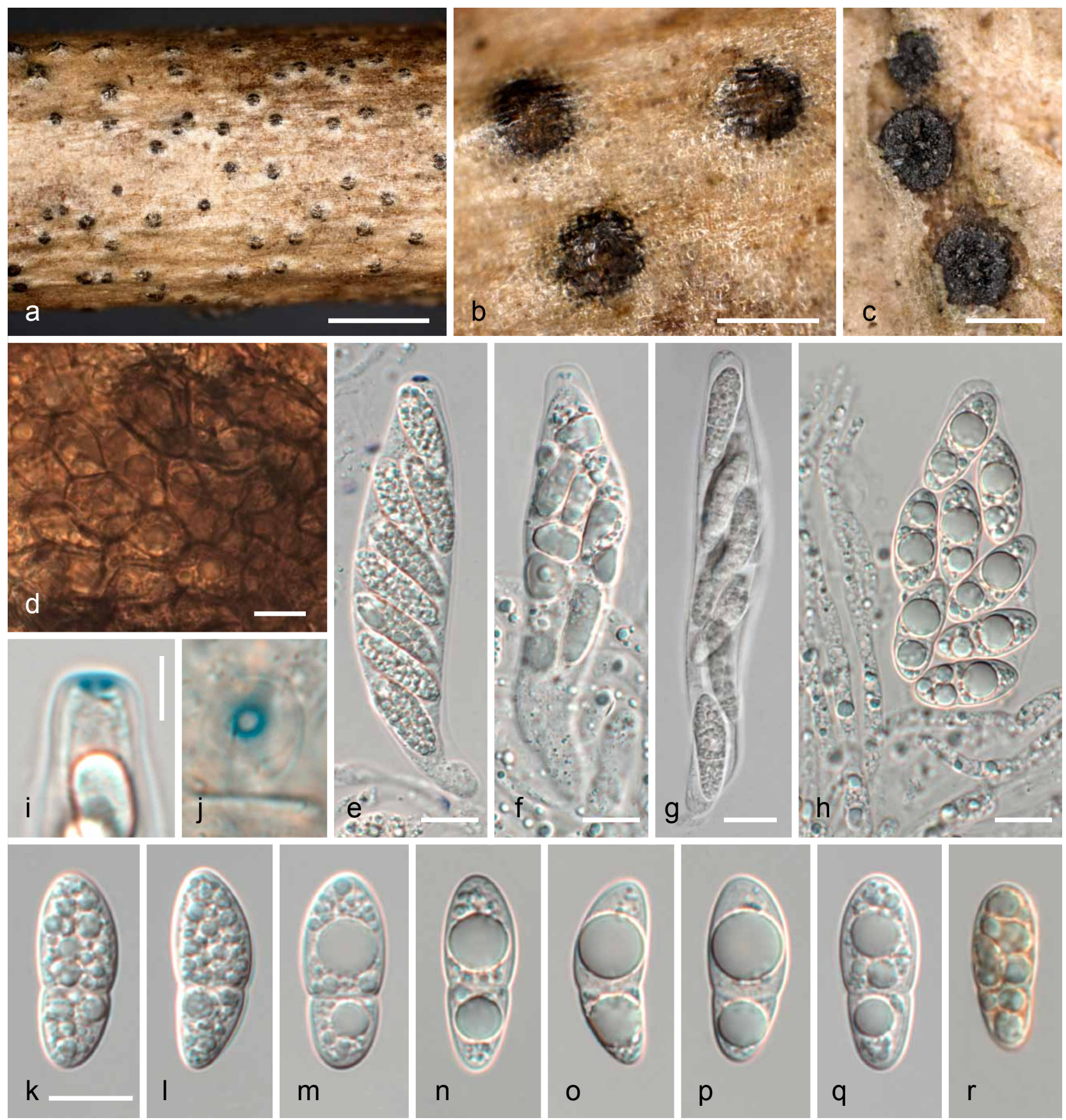

Fig. 5 Pseudapiospora corni. a, b. Ascomata in face view, showing the distinct clypeus; c. black ascomata exposed by epidermis cracks; d. perithecium wall; e-g. immature asci (e. in $3 \% \mathrm{KOH}+$ Lugol; f, g. in $3 \% \mathrm{KOH}$ ); h. mature ascus; i, j. ascus apices in side (i) and face (j) view (in Lugol); k-r. ascospores (r. in Lugol) (a-f, h-r: WU 36852; g: WU 36853). - Scale bars: $a=1 \mathrm{~mm} ; b, c=0.2 \mathrm{~mm} ; \mathrm{d}-\mathrm{r}=10 \mu \mathrm{m}$. 
Pseudomassariaceae Senan. \& K.D. Hyde 2015

Pseudapiospora corni (Sowerby) Petr., Hedwigia 68: 233. 1928 - Fig. 5

Basionym. Sphaeria corni Sowerby, Col. Fig. Engl. Fung. Mushr. (London) 3, 25: pl. 370. 1802.

三Pseudomassaria corni (Sowerby) Arx, Ber. Schweiz. Bot. Ges. 62: 349. 1952.

For additional synonyms see Barr (1964).

Typification. Neotype, here designated: AustrIA, Vienna, 3rd district, Botanical Garden of the University, in bark of Cornus alba cv. elegantissima, 21 Aug. 2015, H. Voglmayr (WU 36852; MBT 202954; ex-neotype culture $\mathrm{PCO}=$ CBS 140736).

Ascomata perithecial, scattered, immersed below rounded, distinct, greyish brown to blackish clypei in slightly elevated epidermis of the host, depressed globose, 170-250 $\mu \mathrm{m}$ wide, corresponding to the width of the clypeus, black. Peridium 10-20 $\mu \mathrm{m}$ wide at the base, thickened up to $50 \mu \mathrm{m}$ toward the apex, of dark brown pseudoparenchymatous cells 5-22 $\mu \mathrm{m}$ diam. Hamathecium of apically free, sparsely branched paraphyses embedded in gel, distinct in water, indistinct in $3 \% \mathrm{KOH}, 1.5-6$ $\mu \mathrm{m}$ wide. Asci in water (60-)65-88(-94) $\times(17-) 18-21(-23)$ $\mu \mathrm{m}(\mathrm{n}=12)$, broadly fusoid, unitunicate, unstable when fresh, disintegrated by pressure, clavate, with 8 irregularly biseriate ascospores and short narrow stipe; apex rounded to attenuated, thickened to c. $1.5 \mu \mathrm{m}$, containing an amyloid ring 2.5-3.7 $\times$ c. $1 \mu \mathrm{m}$, indistinct in water, distinct in $3 \% \mathrm{KOH}$. Ascospores $(17.5-) 20-23.5(-25.5) \times(6.5-) 7.5-9.0(-9.5) \mu \mathrm{m}, \mathrm{I} / \mathrm{w}$ $(2.1-) 2.4-2.9(-3.3)(n=72)$, broadly ellipsoid to clavate, with rounded ends, apiosporous with the septum at or above the lower third of the ascospore, small lower cell (7-)8-10(-11) $\mu \mathrm{m}(\mathrm{n}=25)$ long; straight or curved, thick-walled, smooth; contents of vital spores multiguttulate, commonly with a large and several smaller guttules per cell.

Colonies on MEA and CMD first hyaline to pure white, becoming dark olive grey with age, aerial mycelium cottony on MEA, scant on CMD; reverse first dull whitish, becoming black with age; growth radius at $22^{\circ} \mathrm{C}$ after 6 wk to c. $60 \mathrm{~mm}$ on CMD, to c. $43 \mathrm{~mm}$ on MEA. Ascomata produced on MEA after c. $1 \mathrm{mo},(160-) 190-400(-550) \mu \mathrm{m}$ wide. Asci in $3 \% \mathrm{KOH}$ $(83-) 85-101(-108) \times(14-) 14.3-16.7(-17.5) \mu \mathrm{m}(\mathrm{n}=7)$, oblong to fusoid. Ascospores in $3 \% \mathrm{KOH}(15.5-) 19.3-24.5(-26)$ $\times(5.3-) 6.0-7.2 \mu \mathrm{m}, \mathrm{I} / \mathrm{w}(2.8-) 3.1-3.6(-4)(\mathrm{n}=13)$, similar to, but slightly smaller than, those from ascomata on the natural substrate, with a distinct gelatinous sheath in the ascus. No asexual morph observed.

Habitat - In bark of Cornus alba and C. sericea.

Distribution - Europe, North America.

Additional material examined. AustRIA, Kärnten, Griffen, parking lot of Mochoritsch Griffen-Rast, in bark of Cornus alba, 3 Nov. 2015, H. Voglmayr \& W. Jaklitsch (WU 36855); Oberösterreich, St. Willibald, communal tennis court, in bark of Cornus alba cv. elegantissima, 30 Aug. 2015, H. Voglmayr (WU 36854). - France, 21, Til-Châtel, Le Tertre, 19 Aug. 2015, A. Gardiennet AG15055 (WU 36853, culture PCO1).

Notes - Sowerby (1802) described and illustrated Sphaeria corni, the basionym, from Cornus suecica. No type material is extant in $\mathrm{K}$ (B. Auguirre-Hudson, pers. comm.), where the Sowerby collection is maintained after transfer from BM, and the original illustration is insufficient to serve as lectotype. No specimens from the type host are known to us, but in the lack of a type specimen we consider it desirable to propose a neotype from Cornus alba to maintain the species concept in its current use, in accordance with earlier detailed descriptions (e.g. Petrak 1925, Müller \& Von Arx 1962, Barr 1964, Corlett 1978, 1981). All these descriptions were based on collections from Cornus alba or the closely related $C$. sericea.
Pseudapiospora corni typically occurs on Cornus alba on which it is common. We have not seen it on $C$. sanguinea, and we are not aware of any confirmed records from that host. Senanayake et al. (2015) alleged to treat this fungus under the name Pseudomassaria corni. Based on a specimen collected by E. Camporesi from Cornus sanguinea in Italy, they ignored all earlier detailed descriptions (see above), and made a description and illustration of an immature ascomycete with unicellular ascospores. Apparently this specimen also contains Pseudomassariella vexata, because the ITS sequence (KR092791) obtained from this specimen and deposited by Senanayake et al. (2015) in GenBank represents Pseudomassariella vexata. Apart from few obvious sequencing errors at the very beginning and the end, the sequence is identical with the $P$. vexata exepitype sequence JF440977 published by Jaklitsch \& Voglmayr (2012). At last they defined this specimen even as 'reference specimen of Pseudomassaria corni', which, however, has no formal status as it is not governed by the ICN.

\section{Pseudomassariella vexata (Sacc.) Petr., Sydowia 9: 603. 1955}

Basionym. Didymella vexata Sacc., Michelia 2 (no. 6): 58. 1880.

三 Leiosphaerella vexata (Sacc.) E. Müll., in Müller \& Von Arx, Beitr. Kryptogamenfl. Schweiz 11 (no. 2): 674. 1962.

Typification. Holotype of Didymella vexata: FRANCE, Rouen, Quevilly, on corticated twigs of Cornus sanguinea, J.B.P. Letendre (PAD). Epitype, here designated: AustRIA, Vienna, 3rd district, Botanical Garden of the University, on corticated twigs of Cornus sanguinea, 9 Jan. 2011, H. Voglmayr (WU 31333, ex-epitype culture CBS 129022 = LVE; MBT203100; ITS-LSU sequence JF440977).

Notes - When Fuckel (1871) combined Sphaeria oblitescens in Didymosphaeria, he gave a description of a specimen of his own, which corresponds to $P$. vexata. However, the type of Sphaeria oblitescens represents a true Didymosphaeria (Scheinpflug 1958). Fuckel (1871) noticed differences in the description and illustration from the original fungus, but ascribed this to the "younger state of the fungus in his specimen". Saccardo (1880) received French material from J.B.P. Letendre, noticed that it conforms to Fuckel's fungus and described it as Didymella vexata. In the Didymella folder in PAD there are two specimens labelled $D$. vexata, one collected by Krieger, and a second specimen without any collection data on the specimen which we identify as the holotype. The latter contains a short hand-written Latin description by Saccardo, a drawing of perithecium, asci and ascospores labelled with size ranges identical to those given in the original description, and several small corticated twig fragments. However, the material is scant and not sent out on loan, therefore we epitypify the name with a recently collected specimen which was illustrated in Jaklitsch \& Voglmayr (2012) and for which a culture and sequences are available. See Jaklitsch \& Voglmayr (2012) for a detailed description and illustration. Placement of Pseudomassariella in Pseudomassariaceae receives no bootstrap support (Fig. 1), familial affiliation is therefore provisional.

\section{Requienellaceae Boise 1986, emend.}

Type genus. Requienella Fabre. Other genus in the family: Acrocordiella O.E. Erikss.

Ascomata immersed or erumpent, subglobose; ostiolar necks inconspicuous or massive and strongly erumpent, black; extraascomatal tissue present. Hamathecium comprising two types of apically free paraphyses differing in length and width. Asci bitunicate, fissitunicate, cylindrical, subfusiform to narrowly clavate, with thick-walled apex, wide ocular chamber comprising a slightly refractive, inversely funnel-shaped dome turning slightly reddish in Congo Red, containing 8 uni- to biseriately ar- 
ranged ascospores. Ascospores ellipsoid to oblong, olivaceous or brown, sometimes with lighter ends, with several transverse distosepta and large lumina.

\section{Acrocordiella O.E. Erikss., Mycotaxon 15: 189. 1982}

Type species. Acrocordiella occulta (Romell) O.E. Erikss.

Acrocordiella was described by Eriksson (1982) for the single species Massaria occulta, compared by him with Acrocordia and Pyrenula and assigned to the Pyrenulaceae. Later Boise (1986) and Barr (1990b) treated the genus as a synonym of Requienella. Barr (pers. comm., Jan. 2001) concluded that the genus is "quite separate from Requienella", upon examination of a specimen (W.J. 1537) collected by the senior author in Austria. In order to test this hypothesis, fresh material of this fungus and of Requienella species were recollected, cultured and sequenced. Phylogenetic analyses as well as morphological re-investigations confirmed Acrocordiella to represent a distinct genus closely related to Requienella (see below).

\section{Acrocordiella occulta (Romell) O.E. Erikss., Mycotaxon 15:} 189. 1982 - Fig. 6

Basionym. Massaria occulta Romell, Hedwigia 24: 262. 1885.

इ Hymenopleella occulta (Romell) Shoemaker \& Leclair, Canad. J. Bot. 53: 1587. 1975.

इ Pseudovalsa occulta (Romell) Berl., Icon. Fungorum (Abellini) 1, 1: t. 34 , f. 3. 1890

Lectotype, here designated: SwEDEN, Närke, Kumla, on twigs of Ribes grossularia, 1885, L. Romell, in Winter, Fungi Eur. Extraeur. Exs. 3354 (S, MBT202955). Epitype, here designated: AustRIA, Osttirol, Virgental, Prägraten, Umbalfälle, elev. $1420 \mathrm{~m}$, on dead twigs of Ribes petraeum attached to the shrubs, 17 June 2015, H. Voglmayr \& W. Jaklitsch (WU 33551; MBT202956; ex-epitype culture RS9 = CBS 140500).

Ascomata virtually invisible on the unchanged or sometimes slightly lifted bark, but on the surface often indicated by small white spots 120-300 $\mu \mathrm{m}$ diam around ostiolar openings or independent from them; sometimes, particularly with overmature ascomata, by circular black, non-projecting 50-125 $\mu \mathrm{m}$ wide ostiolar openings with a sunken minute circular perforation. Ascomata immersed in bark, singly or in small groups, within the bark often surrounded by white mycelium of hyaline 2-4 $\mu \mathrm{m}$ wide hyphae, depressed globose to ellipsoid, black, 400-800 $\mu \mathrm{m}$ diam, c. 300-500 $\mu \mathrm{m}$ high. Ostioles containing terminally 1-2.5 $\mu \mathrm{m}$ wide periphyses. Peridium 20-40 $\mu \mathrm{m}$ thick, comprising a textura angularis of small thick-walled angular cells $(2.5-) 3.0-7.5(-12.5) \mu \mathrm{m}(\mathrm{n}=32)$ diam. Hamathecium of apically free, scarcely branched, $2-5 \mu \mathrm{m}$ wide regular paraphyses, sometimes with basal cells inflated to $7 \mu \mathrm{m}$, and numerous, variously curved, $1-2.5(-3) \mu \mathrm{m}$ wide elongated paraphyses in a gel matrix. Asci emerging from the base and sides of the ascoma nearly up to the ostiole, (150-)160-183(-191) $\times(11.5-) 12-16.5(-21.7) \mu \mathrm{m}(\mathrm{n}=23)$, cylindrical, attenuated toward the apex, containing 8 (obliquely) uniseriate ascospores, not obviously fissitunicate, thin-walled; apex attenuated and distinctly thickened, containing a slightly refractive, inversely funnel-shaped canal 4-5.5 $\mu \mathrm{m}$ high, 3-5.7 $\mu \mathrm{m}$ diam, extending up to $11 \mu \mathrm{m}$ in $3 \% \mathrm{KOH}$, staining blue in aqueous Cotton Blue and faintly reddish in Congo Red; base simple or knob-like. Ascospores (16.5-)20-24.3(-27.7) $\times(6.8-) 8.3-10(-11) \mu \mathrm{m}, \mathrm{I} / \mathrm{w}$ $(1.8-) 2.2-2.7(-3.2)(n=70)$, ellipsoid, ends narrowly rounded to nearly acute, straight to slightly curved, olivaceous, greyish olive when young, dark brown when dead, 3-distoseptate, lumina rhomboid to square-shaped, central ones slightly larger than terminal ones, multiguttulate, sides often slightly pinched, smooth, without sheath; in $\mathrm{KOH}$ more angular and eventually terminal distosepta disappearing; darkening in Lugol; turning pale brown in Cotton Blue/lactic acid.
Culture characteristics - Growth slow; decreased temperates $\left(15-22^{\circ} \mathrm{C}\right)$ required; colonies white. No asexual morph observed.

Habitat - In bark of Ribes spp.

Distribution - Central, Eastern and Northern Europe (Austria, Russia, Sweden).

Additional material examined. AustriA, Osttirol, Virgental, Prägraten, Umbalfälle, elev. 1450 m, on dead twigs of Ribes petraeum, 17 June 2015, W. Jaklitsch \& H. Voglmayr (WU 33552, culture RS10 = CBS 140501); ibid., 28 Aug. 2000, W. Jaklitsch W.J. 1537 (WU 33550). - SwEden, Närke, Kumla, on Ribes grossularia; 29 June 1889, L. Romell, Fungi exs. praes. scand. 73 (GZU).

Notes - As the epithet implies, $A$. occulta is an inconspicuous fungus, well hidden in the bark. This character, a simpler ascus apex, a different ascospore anatomy, different ecology and the results of phylogenetic analyses clearly demonstrate that Acrocordiella is not congeneric with Requienella. Previously only known from Ribes uva-crispa $(=R$. grossularia) in Scandinavia and from Ribes nigrum in Russia, it was also collected in Austria in 2000 (Hausknecht et al. 2003), but not cultured at that time. Cultures were prepared from specimens collected recently in the same area.

Requienella Fabre, Ann. Sci. Nat., Bot., sér. 6, 15: 55. 1883

= Trematomyces Schrantz, Bull. Soc. Mycol. France 76: 324. 1961.

Type species. Requienella seminuda (Pers.) Boise.

Boise (1986) described the family Requienellaceae for Requienella Fabre in the Dothideomycetes (as Loculoascomycetes). She lectotypified Requienella with $R$. olearum, determined its earliest epithet as Sphaeria seminuda Pers. 1801 and stated that the three other species recognised by Fabre (1883) in $R e$ quienella belonged to other genera. The family Requienellaceae was not accepted by Eriksson (in Eriksson \& Hawksworth 1986) and he maintained Requienella in the Pyrenulaceae. He also supposed that the 'non-branched pseudoparaphyses' are true paraphyses, as in Pyrenula. Barr (1990b) listed the Requienellaceae as a family of her order Melanommatales. Aptroot (1991) accepted Barr's system, treated the Pyrenulales as synonym of the Melanommatales and added five genera of lichenised fungi to the non-lichenised Requienella in the Requienellaceae. Harris (1995) considered to accept the Requienellaceae but being only restricted to the single genus Requienella. Kirk et al. (2008) listed the Requienellaceae as a family of the Pyrenulales. Here we show that Requienella surprisingly belongs to the Xylariales, despite its fissitunicate asci.

\section{Requienella seminuda (Pers.) Boise, Mycologia 78: 38. 1986} — Fig. 7

Basionym. Sphaeria seminuda Pers., Syn. Meth. Fung. (Göttingen) 1: 70. 1801.

= Sphaeria olearum Castagne, Cat. Pl. Marseille: 116. 1845 [non Sphaeria olearum De Not., 1845, nom. illegit., art. 53.1].

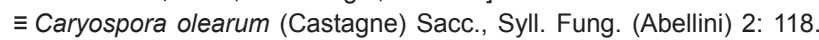
1883.

इ Requienella olearum (Castagne) Fabre, Ann. Sci. Nat., Bot., sér. 6, 15: 1883.

$\equiv$ Trematosphaeria olearum (Castagne) Sacc., Syll. Fung. (Abellini) 2: 118. 1883.

$\equiv$ Trematomyces olearum (Castagne) Schrantz, Bull. Trimestriel Soc. Mycol. France 76: 323. 1961.

Typification. Lectotype of Sphaeria seminuda designated by Boise (1986): ?FRANCE, Herb. Persoon L0113128 (= 910269-31, L!). Epitype, here designated: GREECE, Crete, Rethymno, Armeni, on bark of Olea europaea, 9 June 2015, H. Voglmayr \& W. Jaklitsch (WU 33568; MBT 202957; ex-epitype culture RS12 = CBS 140502). 

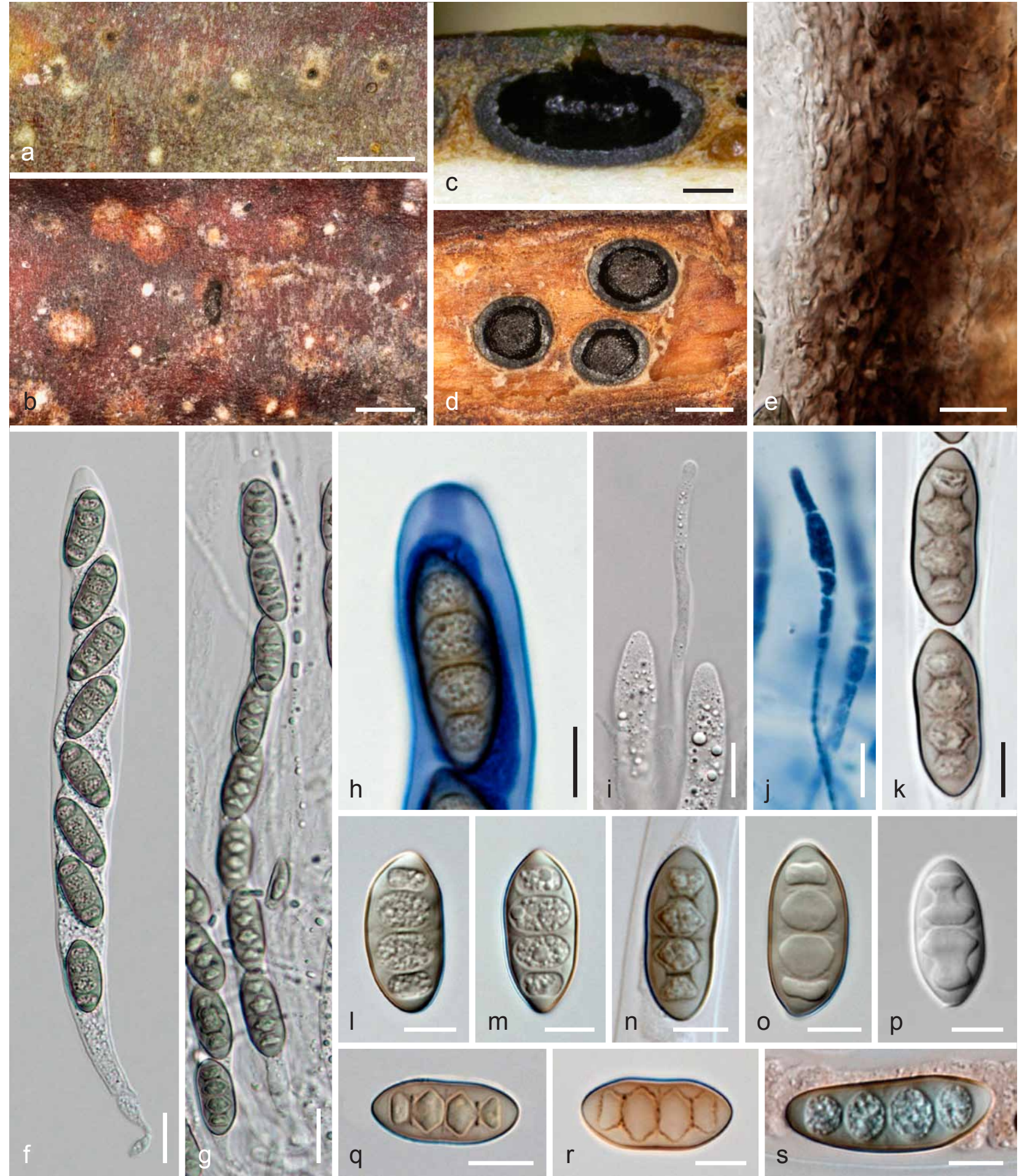

Fig. 6 Acrocordiella occulta. a, b. Ostioles and white spots on the bark surface; c. ascoma in vertical section; d. ascomata in transverse section; e. ascomatal wall in section; f, g. asci; h. ascus apex in aqueous Cotton Blue; i. paraphysis between young asci; j. elongated paraphysis in aqueous Cotton Blue; k-s. ascospores (k, n. in $3 \% \mathrm{KOH}$; o, p. dead, in water; q. in Lugol; r. in Cotton Blue/lactic acid; s. in Congo Red) (a, k: GZU; b-j, I-s: WU 33551). - Scale bars: $a, d=0.5 \mathrm{~mm} ; \mathrm{b}=0.8 \mathrm{~mm} ; \mathrm{c}=150 \mu \mathrm{m} ; \mathrm{e}, \mathrm{i}, \mathrm{q}=10 \mu \mathrm{m} ; \mathrm{f}, \mathrm{g}=15 \mu \mathrm{m} ; \mathrm{h}, \mathrm{j}-\mathrm{p}, \mathrm{r}, \mathrm{s}=7 \mu \mathrm{m}$.

Ascomata solitary or aggregated in groups of $2-5$, perithecioid, conical with rounded base or more or less globose with a prominent apex, immersed, large, (0.35-)0.45-0.9(-1.1) mm diam, 0.6-1.2 $\mathrm{mm}$ high, often height exceeding the diam, often surrounded by whitish, greyish to black matter. Ostiolar neck erumpent, massive, papillate to conical, shiny black, apex typically $25-160 \mu \mathrm{m}$ wide, round, blunt to pointed, sometimes flattened and 90-300 $\mu \mathrm{m}$ diam. Peridium 15-40 $\mu \mathrm{m}$ wide at the base, thickened to $160 \mu \mathrm{m}$ in upper regions, dark brown, consisting of minute thick-walled angular cells. Hamathecium consisting of 2-5 $\mu \mathrm{m}$ wide, apically free paraphyses similarly long as the asci, and numerous long, not or scarcely branched,
1-2.5 wide, apically free elongated paraphyses ('pseudotrabeculae') nearly reaching the ostiolum, and periphyses of similar width in the ostiolum, all immersed in a gel matrix. Asci $(148-) 158-178(-182) \times(21.7-) 23.5-29(-32.5) \mu \mathrm{m}(\mathrm{n}=13)$, bitunicate, fissitunicate, oblong to subfusiform, with thick-walled apex, wide ocular chamber comprising a slightly refractive, inversely funnel-shaped dome 5.5-7 $\mu \mathrm{m}$ high, 6.5-7.7 $\mu \mathrm{m}$ wide at the base, turning slightly reddish in Congo Red, demarcated by a basal plate, with short stipe and simple to knob-shaped base, containing 8 uni-, in the middle often biseriately arranged ascospores. Ascospores (25.3-)28.3-32.7(-37) × (9.8-)10.812.7(-13.3) $\mu \mathrm{m}, \mathrm{I} / \mathrm{w}(2.2-) 2.3-2.9(-3.7)(\mathrm{n}=50)$, first hyaline, 

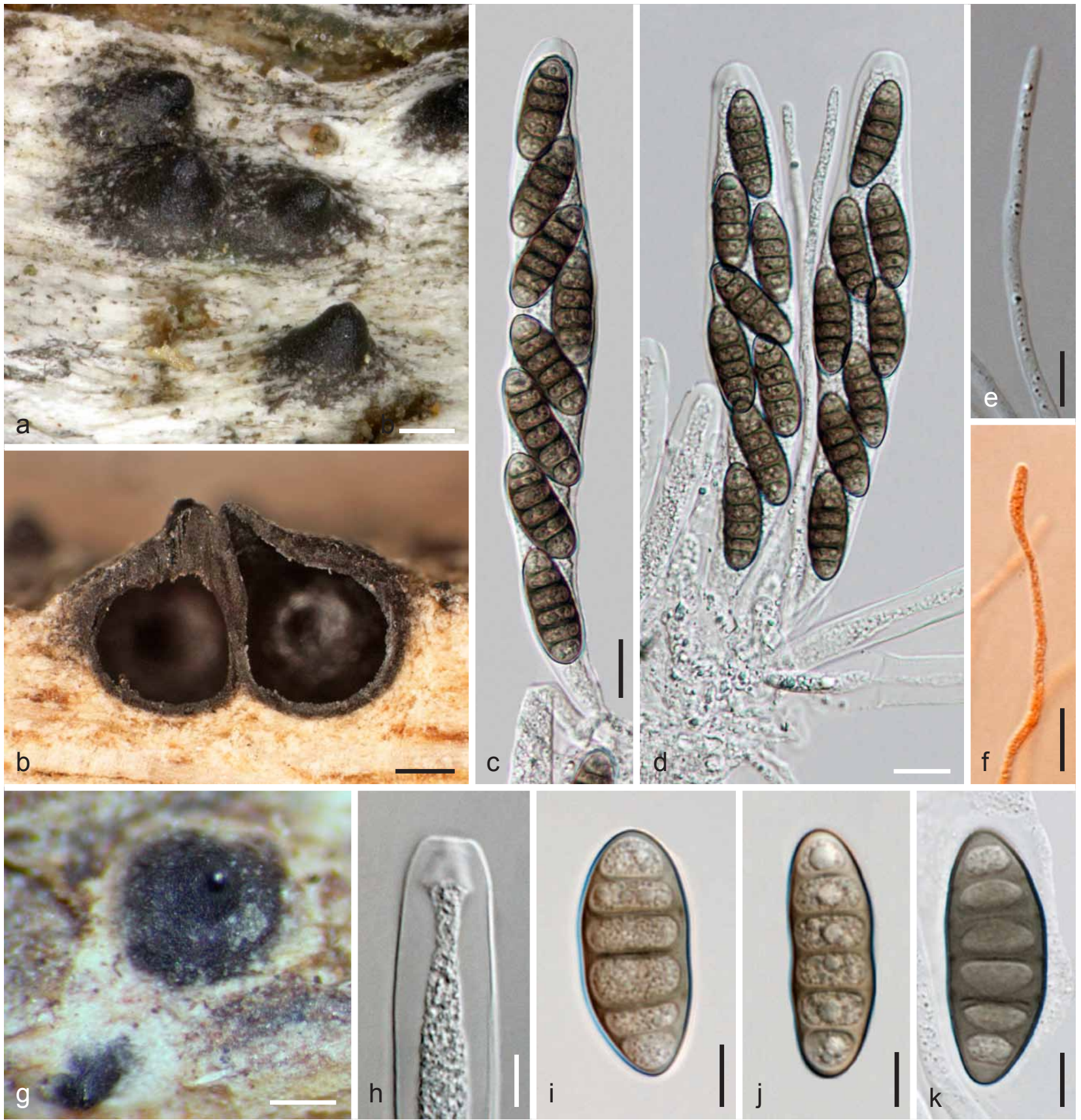

Fig. 7 Requienella seminuda. a, g. Ascomata in face view; b. ascomata in vertical section; c, d. asci (note apically free paraphyses in d); e. apically free paraphysis; f. free apex of elongated paraphysis (in Congo Red); h. ascus apex; i-k. ascospores (a, c, f, h, j: WU 33569; b, i: WU 33567; d, e, k: WU 33568; g: lectotype L0113128). - Scale bars: $a, b, g=0.2 \mathrm{~mm} ; \mathrm{c}, \mathrm{d}=15 \mu \mathrm{m} ; \mathrm{e}, \mathrm{h}-\mathrm{k}=7 \mu \mathrm{m} ; \mathrm{f}=10 \mu \mathrm{m}$.

1-celled, inequilateral, developing 1-3 septa and turning brown with slightly paler end cells, becoming (3-)5(-7)-distoseptate, ellipsoid, with the width lumina exceeding their length, turning darker olivaceous in $\mathrm{KOH}$ and lumina becoming smaller and more angular.

Culture characteristics - Growth of cultures extremely slow (few mm per month), only somewhat enhanced by overlay of sterile water; colonies white. No asexual morph observed.

Habitat - In dead bark, less commonly wood of living trunks of old Olea europaea trees.

Distribution - Southern and Western Europe (France, Greece, Italy).

Additional material examined (all from bark of Olea europaea). GREECE, Crete, Chania, Platanias, Pananiana, 4 June 2015, H. Voglmayr \& W. Jaklitsch (WU 33566); Rethymno, Ambelaki, 9 June 2015, W. Jaklitsch \& H. Voglmayr (WU 33567, culture RS11); Vizari, 9 June 2015, W. Jaklitsch \& H. Voglmayr (WU 33569, culture RS13).
Notes - Requienella seminuda is a peculiar fungus. Its distinctly fissitunicate asci have prevented a placement outside groups of ascomycetes with bitunicate asci. The hamathecium has never been studied in detail resulting in controversial reports: Barr (1990b) found narrow, scarcely branched trabeculae, whereas Eriksson (in Eriksson \& Hawksworth 1986) anticipated that the 'non-branched pseudoparaphyses' are probably true paraphyses. Peculiar is the fact that three kinds of threads are present, a mass of numerous long and extremely narrow hyphae with free ends extending to the upper part of the ascoma ('pseudo-trabeculae'), wider 'normal' paraphyses between asci, best seen among immature asci, and periphyses in the ostiole. It is difficult to determine the nature of the entire hamathecium. As a matter of fact, all threads appear to have free ends, which suggests that some paraphyses are strongly elongated and taper upwards forming long straight 'pseudo-trabeculae' at upper levels of the ascoma. In any case, the presence of true paraphyses is in line with other Sordariomycetes, as are the 
sequences of the phylogenetic markers used here. According to Fabre (1883) and Saccardo (1883) ascospores of $R$. seminuda are 5- or more-septate. We found only rarely a number of septa deviating from five.

Nomenclatural background: Sphaeria olearum was based on a specimen collected by Desmazières. Boise (1986), upon examination of an ?isotype of this material from NY and of Persoon's type material of Sphaeria seminuda from Leiden, determined that they represent the same species, that $S$. seminuda is older than S. olearum and chose Persoon's material as lectotype. She also illustrated regularly 5-distoseptate ascospores for Persoon's material L0113128 (=910269-31, L!). Later Aptroot (1991) examined the original type material of Sphaeria olearum (France, Bouches-du-Rhône, Desmazières 1767) present in G and confirmed conspecificity of the two taxa. We examined and illustrate ascomata of the lectotype of $R$. seminuda. As Boise
(1986) illustrated 5-distoseptate ascospores for the lectotype, we conclude that Persoon's material, like Desmazières's original material, originates from Olea europaea, most probably from France. We epitypify $S$. seminuda with material from Olea, due to an earlier mix-up of $R$. seminuda by several authors with Acrocordiella occulta and Requienella fraxini described below.

Requienella fraxini Jaklitsch \& Voglmayr, sp. nov. - MycoBank MB814828; Fig. 8

Etymology. Referring to its occurrence on Fraxinus.

Holotype. NoRWAY, Akershus, Bærum kommune, Jonsrudtjern, UTM 32 : 0580011/6649407, at the steep slope of the small lake, soc. Navicella pileata 18 Sept. 2012, B. Norden (WU 33561, ex-type culture RS3 = CBS 140475).

Ascomata perithecioid, immersed, with the ostiolum, often including an upper part of the ascoma, erumpent to $0.2-0.9 \mathrm{~mm}$
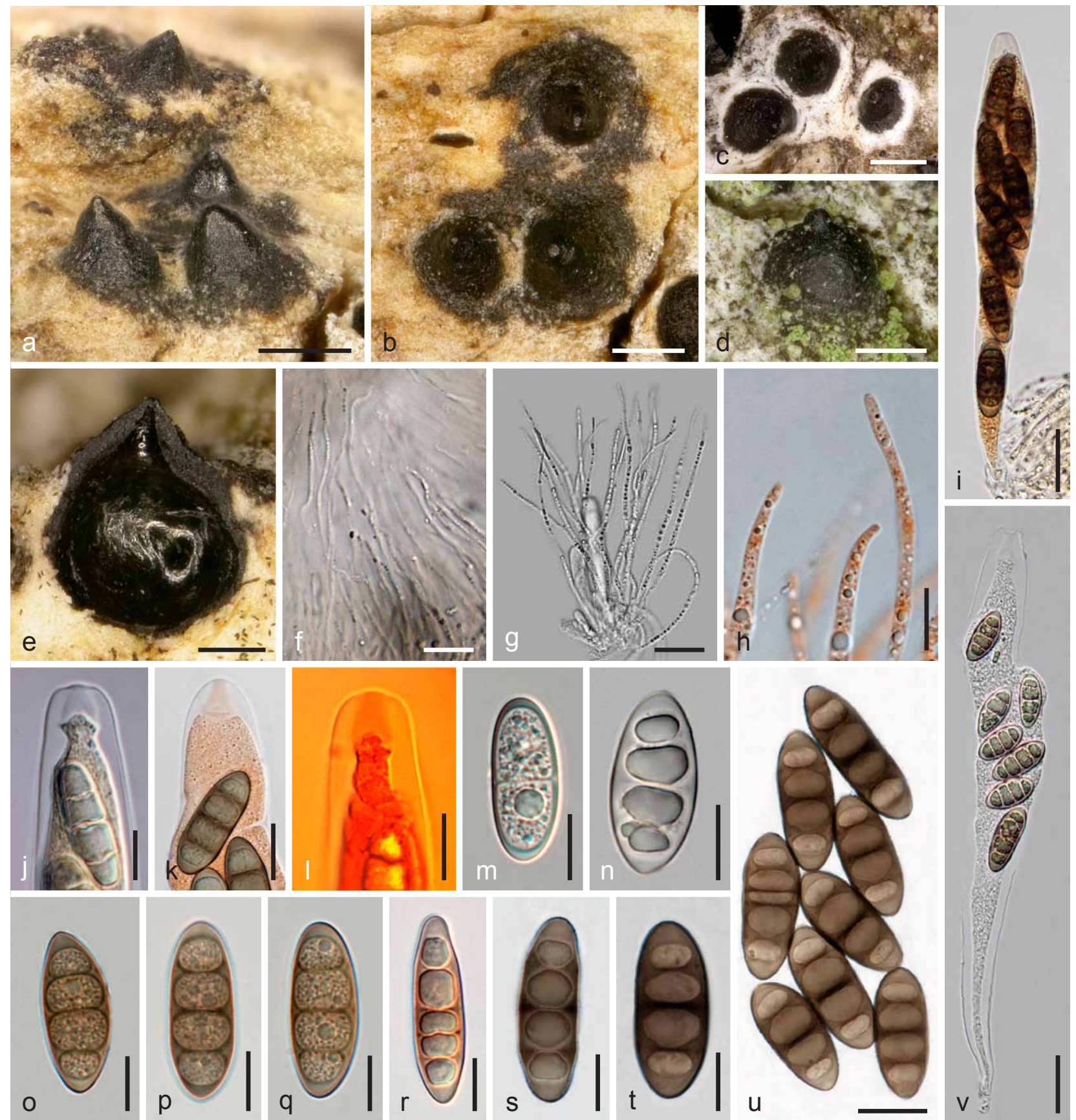

Fig. 8 Requienella fraxini. a-d. Ascomata in face and lateral views; e. ascoma in vertical section (note wall thickening in ostiolar region); f. hamathecium in the upper ascomatal region; g. young asci with paraphyses; $h$. free apical ends of paraphyses; i, v. asci ( $\mathrm{i}$ in Lugol; note fissitunicate dehiscence in v); j-I. ascus apices (k. in Lugol + Congo Red; I. in Lugol); m-u. ascospores (m, n. immature; o-q. vital) (a, b: WU 33560; c, d: WU 33564; e-i, k, n, s-v: WU 33561; j, I: WU31483; m, o-q: WU 33565; r: WU31482). - Scale bars: a-d = $0.5 \mathrm{~mm} ; \mathrm{e}=0.3 \mathrm{~mm} ; \mathrm{f}, \mathrm{i}, \mathrm{v}=25 \mu \mathrm{m} ; \mathrm{g}=50 \mu \mathrm{m} ; \mathrm{h}, \mathrm{j}, \mathrm{I}-\mathrm{t}=10 \mu \mathrm{m} ; \mathrm{k}, \mathrm{u}=15 \mu \mathrm{m}$. 
above the host surface, solitary or aggregated in small numbers, $0.5-1.1 \mathrm{~mm}$ high, $0.45-1 \mathrm{~mm}$ diam, conical with rounded base or more or less globose with a prominent, conical, more or less acute, shiny black, apically $26-160 \mu \mathrm{m}$ wide papilla, circular in transverse section, black; often surrounded by white amorphous tissue containing some hyaline 2-6 $\mu \mathrm{m}$ wide hyphae; tissue sometimes turning black by ejected ascospores. Peridium $15-30 \mu \mathrm{m}$ wide at the base, thickened to $150 \mu \mathrm{m}$ and hard in upper regions, dark brown, consisting of small pseudoparenchymatous cells. Hamathecium complex, consisting of 2-5 $\mu \mathrm{m}$ wide, apically free paraphyses containing oil drops when vital, and similarly long as the asci, superposed by masses of long, sparcely branched, 1-2.5 wide, apically free 'pseudotrabeculae' nearly reaching the ostiolum and variously curved periphyses of same width in the ostiolum, all immersed in a gel matrix. Asci 153-206 × 20-30 $(-33) \mu \mathrm{m}(\mathrm{n}=10)$, bitunicate, fissitunicate, oblong to narrowly clavate, with thick-walled apex, wide ocular chamber comprising a slightly refractive, inversely funnel-shaped dome 9-11 $\mu \mathrm{m}$ long, 6.5-9.5 $\mu \mathrm{m}$ wide at the base, turning reddish in Congo Red, demarcated by a basal plate, with short simple stipe, containing 8 uni- to biseriately arranged ascospores. Ascospores (23.3-)26.7-31.5(-36) $\times$ (8.0-)9.5-12(-14.5) $\mu \mathrm{m}, \mathrm{I} / \mathrm{w}(2.1-) 2.4-3.1(-3.9)(\mathrm{n}=100)$, ellipsoid, oblong to fusiform, first hyaline, 1-celled, with narrow sheath, becoming septate and yellow, finally brown with lighter ends, 3(-5)-distoseptate, with large lumina and faintly punctate perispore.

Culture characteristics - Growth of cultures extremely slow, only somewhat enhanced by overlay of sterile water; colonies white. No asexual morph observed.

Habitat - In bark of living trunks of old trees of Fraxinus excelsior.

Distribution - Northern and Western Europe (France, Norway, Sweden), probably North America.

Additional material examined (all from bark of Fraxinus excelsior). FRANCE, Poitou-Charentes, Le Vanneau, Marais Poitevin, 30 Oct. 2013, A. Gardiennet AG13205 (WU 33564 = RS7; culture lost). - NoRWAY, Akershus, Bærum kommune, Jonsrudtjern, UTM 32: 0580020/6649407, 18 Sept. 2012, B. Norden (WU 33560, culture RS2); Akershus, Rogaland kommune, Strand, Rag, UTM 32: $26104 / 55362,4$ Oct. 2012, B. Norden \& J.B. Jordal (WU $33563=$ RS4); Bærum kommune, Tanumbråtan north, UTM 32: 0582366/6640274, 20 Sept. 2012, B. Norden (WU 33562); Vest-Agder, Kristiansand kommune, Nedre Timenes, 5 Oct. 2014, H. Voglmayr \& W. Jaklitsch (WU 33565, culture RS8 = CBS 140476). - SwEDEN, Västra Götaland, Bohuslän, Uddevalla, Ljungskile, 1 Apr. 2001, N. Vassbosjön (WU 31582); Blekinge, Angölsmåla, Olofström, Kyrkhult, 27 Apr. 2002, B. Norden (WU 31583).

Notes - Prior to the recent recollection of Requienella seminuda on Olea europaea we identified $R$. fraxini as $R$. seminuda, following Boise (1986). However, molecular data clearly separate these two species. Moreover, the description of $R$. seminuda by Boise (1986), Aptroot (1991) and Barr (1990b) as having regularly 3-6-, or 3-7-septate ascospores suggested that the different septations occur at comparable frequencies. This is, however, not the case, as ascospores of $R$. seminuda are regularly 5 -septate and those of $R$. fraxini 3 -septate. In each species only a very small fraction may have deviant numbers of septa. This is also supported by the description of ascospores for $R$. olearum as 5 - or more septate by all authors dealing with the taxon in the 19th century. Distinction criteria other than ascospore septation are different hosts (Olea vs Fraxinus) and the geographical distribution, $R$. fraxini in northern humid regions, $R$. seminuda in southern mediterranean regions of Europe, with southern France as an overlapping zone. Requienella fraxini appears to be confined to old trees in areas of high humidity and is therefore much rarer than its host. It may be in decline and endangered due to ash dieback. Nordén \& Jordal (2014) gave an account of $R$. fraxini under the name $R$. seminuda, i.e. before we collected $R$. seminuda on Olea.
Sporocadaceae Corda (as 'Sporocadeae'), Icon. Fungorum (Prague) 5: 34. 1842

Type genus. Sporocadus Corda, Icon. Fungorum (Prague) 3: 23. 1839 (synonymous with Seimatosporium Corda, in Sturm, Deutschl. Fl., Abt. 3, Pilze Deutschl. 3: 79. 1833.)

Hughes (1958) lectotypified Sporocadus with S. lichenicola, which is currently known as the plurivorous species Seimatosporium lichenicola, the asexual morph of Discostroma corticola (Shoemaker \& Müller 1964), currently being treated as a synonym of $D$. fuscellum.

\section{Hymenopleella Munk, Dansk Bot. Ark. 15: 89. 1953}

Type species. Hymenopleella hippophaëicola Jaklitsch \& Voglmayr.

Ascomata perithecial, immersed in bark, depressed globose. Ostioles periphysate. Peridium pseudoparenchymatous, 2-layered. Hamathecium of apically free paraphyses. Asci cylindrical, with 8 uni- to partially biseriate ascospores, containing a flat, $\mathrm{V}$-shaped to sinuous, amyloid apical ring. Ascospores oblong, ellipsoid or fusoid, symmetric, with several eusepta, light yellow- to reddish brown wall and septa more strongly pigmented than contents, smooth, partly turning dull green in Lugol, lacking a sheath. Asexual morph monochaetia-like.

\section{Hymenopleella hippophaëicola Jaklitsch \& Voglmayr, nom.} nov. - MycoBank MB814829; Fig. 9

Etymology. Referring to its occurrence on Hippophaë.

Replaced synonym. Sphaeria hippophaës Sollm., Bot. Zeitung 20: 379 1862, non Hymenopleella hippophaës (Fabre) Rulamort, Bull. Soc. Bot. Centre-Ouest, Nouv. sér. 17: 192. 1986.

三 Leptosphaeria hippophaës (Sollm.) Sacc., Syll. Fung. (Abellini) 22: 222. 1913

इ Lepteutypa hippophaës (Sollm.) Arx, Gen. Fungi Sporul. Cult. (Lehr): 118. 1970.

三 Massaria hippophaës (Sollm.) Jacz., Bull. Herb. Boissier 2: 684. 1894

三 Hymenopleella sollmannii Shoemaker \& E. Müll., Canad. J. Bot. 43: 1457. nom. inval. Art. 52.1

= Melanomma hippophaës Fabre, Ann. Sci. Nat., Bot., sér. 6, 9: 92. 1878.

इ Hymenopleella hippophaës (Fabre) Munk, Dansk Bot. Ark. 15: 90. 1953, nom. inval. Art. 41.5

三 Hymenopleella hippophaës (Fabre) Rulamort, Bull. Soc. Bot. CentreOuest, Nouv. sér. 17: 192. 1986.

Typification. No holotype seems to be extant, but there is an authentic specimen present in B, which was collected by the author of the replaced synonym, August Sollmann, two years after his publication. We designate this specimen as neotype of Sphaeria hippophaës: GeRmany, Coburg, on twigs of Hippophaë rhamnoides, 1864, A. Sollmann (B700021868; MBT203103). Epitype, here designated: AustrIA, Niederösterreich, Gerasdorf, Marchfeldkanalweg, on twigs of Hippophaë rhamnoides, 12 Aug. 2012, W. Jaklitsch (WU 32027; MBT202958; ex-epitype culture LH = CBS 140410).

Ascomata perithecial, immersed in bark, scattered or in small groups, $0.2-0.4(-0.5) \mathrm{mm}$ diam, lifting the bark only slightly producing inconspicuous irregular bumps with small black ostiolar dots 30-80 $\mu \mathrm{m}$ diam. Ostioles 25-50 $\mu \mathrm{m}$ wide inside, central, short-papillate, periphysate; peridium 20-40 $\mu$ m thick, pseudoparenchymatous, of a thin hyaline inner layer and a dense small-celled dull orange-brown outer textura angularis, sometimes surrounded by some whitish, buff to brown hyphal tissue. Paraphyses uncommon, simple, rarely branched, 3-5 $\mu \mathrm{m}$ wide. Asci (90-)97-126(-134) × (12-)12.5-16(-17) $\mu \mathrm{m}$ $(n=14)$, cylindrical, with 8 (partly obliquely) uniseriate, rarely more or less biseriate ascospores, with a short stipe; apex thickened to $2 \mu \mathrm{m}$ (to $3.5 \mu \mathrm{m}$ when young), containing a flat, V-shaped to sinuous, amyloid apical ring (4.0-)4.5-5.3(-5.5) $\times(0.7-) 0.8-1.2(-1.5) \mu \mathrm{m}(\mathrm{n}=17)$. Ascospores $(15.2-) 17.5-$ $22.5(-26.5) \times(7.2-) 8.0-9.0(-9.7) \mu \mathrm{m}, \mathrm{l} / \mathrm{w}(1.8-) 2.1-2.7(-3.3)$ $(n=100)$, oblong, ellipsoid or fusoid, symmetric, ends rounded 

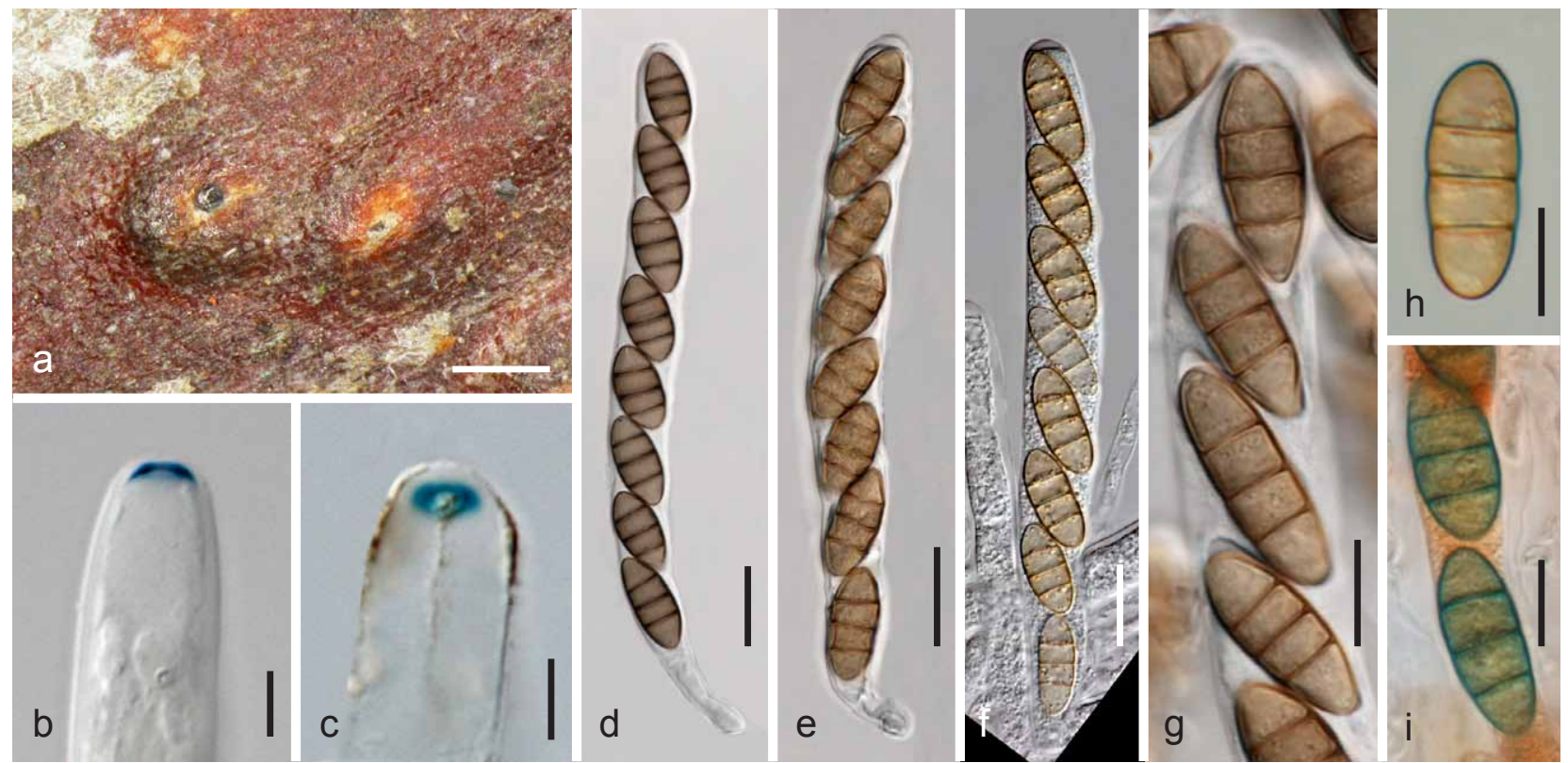

Fig. 9 Hymenopleella hippophaëicola. a. Ostioles and bumps on the bark surface; b, c. ascus rings in Lugol; d-f. asci (d, e. in 3 \% KOH); g-i. ascospores (g. in $3 \% \mathrm{KOH}$; i. in Lugol) (a, b, d, e, g: B700021868; c, f, h, i: WU 32027). - Scale bars: a = 0.2 mm; b, c = $5 \mu \mathrm{m}$; d-f = $15 \mu \mathrm{m}$; g-i = $10 \mu \mathrm{m}$.

or attenuated, with 3 non-constricted eusepta, straight or slightly curved, light yellow- to reddish brown, darker brown in $\mathrm{KOH}$, wall and septa more strongly pigmented than contents, smooth, partly turning dull green in Lugol, lacking a sheath.

Culture characteristics - Growth better on MEA than on $\mathrm{CMD}$ and better at $15^{\circ} \mathrm{C}$ than at room temperature; colony first whitish, turning greyish brown to olive. No asexual morph observed here, but reported by Shoemaker \& Müller (1965; under Hymenopleella sollmannii) from malt agar: Conidia formed in spherical cavities $140-300 \mu \mathrm{m}$ diam, surrounded by a $15-50$ $\mu \mathrm{m}$ thick wall of reddish brown hyphae. Conidiophores hyaline, simple, $10-30 \times 2-3 \mu \mathrm{m}, 1-2-$ septate, with fine annellations. Conidia fusoid, $20-27 \times 6-9 \mu \mathrm{m}$, straight or rarely curved, mostly 4-septate, with medium yellow-brown central cells and colourless end cells, apical cell with an acuminate 3-6 $\mu \mathrm{m}$ long appendage sometimes separated by an additional septum, basal cell narrowed to $3 \mu \mathrm{m}$ wide truncate base usually bearing a central, 2-4 $\mu \mathrm{m}$ long appendage.

Habitat - In bark of Hippophaë rhamnoides.

Distribution - Europe.

Additional material examined. AustRIA, Vienna, 21st district, Donauinsel, grid square 7764/3, on twigs of Hippophaë rhamnoides, 20 June 1999, W. Jaklitsch W.J. 1326 (WU 32027).

Notes - A detailed description of Hymenopleella hippophaëicola was given by Petrak (1947) under the name Leptosphaeria hippophaës. Ascospores mature asynchronously, starting from the ascus base. The taxonomic and nomenclatural history of this species is complicated. Munk (1953) based Hymenopleella on Melanomma hippophaës Fabre, which is younger than Sphaeria hippophaës Sollm. Winter (1887) recognised that these heterotypic names represent the same species, which was confirmed by Shoemaker \& Müller (1965). Therefore Shoemaker \& Müller (1965) introduced the new name Hymenopleella sollmanni as a replaced synonym for Sphaeria hippophaës Sollm., non Hymenopleella hippophaës (Fabre) Munk. However, they missed that, according to Art. 41.5 of the ICN, the combination Hymenopleella hippophaës (Fabre) Munk is invalid, as Munk (1953) did not give a reference to the place of valid publication of the basionym. Therefore, according to Art. 52.1 of the ICN, Hymenopleella sollmannii is a superfluous, illegitimate new name. However, since De Rulamort (1986) validated the combination Hymenopleella hippophaës based on
Melanomma hippophaës Fabre, Sphaeria hippophaës Sollm. cannot be combined in Hymenopleella any more, and a new replacement name is necessary. Shoemaker \& Müller (1965) accepted Hymenopleella as different from Lepteutypa due to the ascospores of Lepteutypa fuckelii, in being 'narrower and thinner-walled, octagonal in section and having a sheath and a peculiar brown deposit in the middle line of each septum'. In our experience, a more striking difference is the euseptate nature of ascospores in $\mathrm{H}$. hippophaëicola as opposed to distoseptate in L. fuckelii.

\section{Seiridium Nees, Syst. Pilze (Würzburg): 22. 1816}

Type species. Seiridium marginatum Nees.

Seiridium is characterised by acervular coelomycetes with versicolorous, 5-septate, appendaged conidia. Its type species Seiridium marginatum Nees 1816 (not Seiridium marginatum Schwein. 1832, a later homonym representing a rust fungus species of Phragmidium), was redescribed by Sutton (1980) and Shoemaker et al. (1966), who described its sexual morph as Blogiascospora marginata, based on co-occurrence. Here we confirm this relationship using DNA data.

Seiridium marginatum Nees, Syst. Pilze (Würzburg): 23. 1816 - Fig. 10

(non Seiridium marginatum Schwein., Trans. Amer. Philos. Soc., n.s. 4: 306. 1832 [1834].)

= Blogiascospora marginata (Fuckel) Shoemaker, E. Müll. \& MorganJones, Canad. J. Bot. 44: 248. 1966.

三 Massaria marginata Fuckel, Jahrb. Nassauischen Vereins Naturk. 2728: 28. 1874.

Typification. Neotype of Seiridium marginatum, proposed by Shoemaker et al. (1966): SwitzerLAnd, Jura, on twigs of Rosa, in spring, P. Morthier, in Fuckel, Fungi Rhen. Exs. 2136 (previously BM; now K(M) 200376). Epitype, here designated: FRANCE, Burgundy, Côte-d'Or, Til-Chatel, on twigs of Rosa canina; holomorph, 1 Apr. 2015, A. Gardiennet AG15018 (WU 33575; MBT202960; ex-epitype culture from ascospores: CBS $140403=$ BLO; culture from conidia: SEI).

Sexual morph visible through bark fissures as pale brownish spots with a central black papilla or, after removal of upper bark layers, as flattened greyish to brownish pustules $0.2-0.6$ $\mathrm{mm}$ diam. Ascomata perithecial, immersed in bark, depressed 

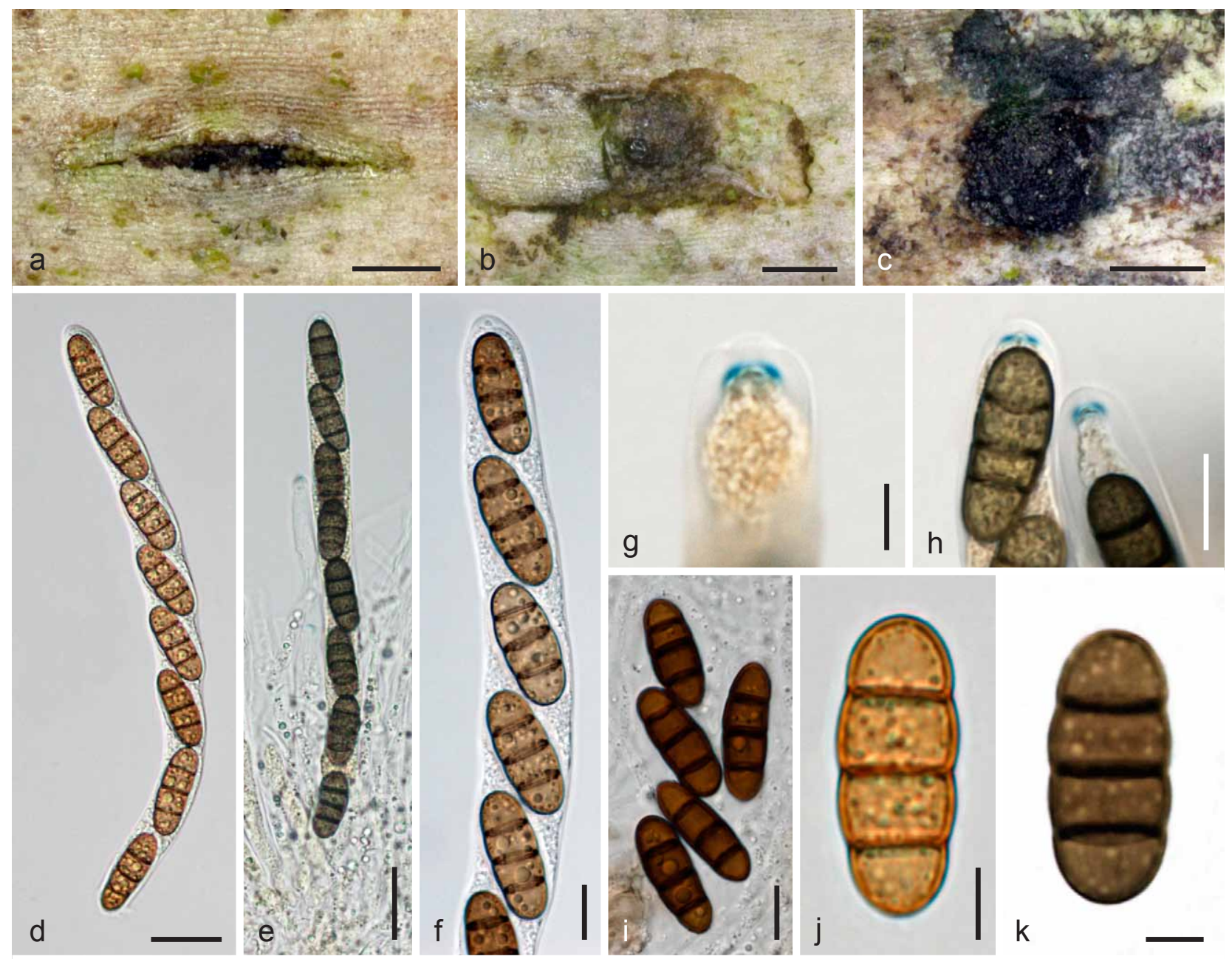

g
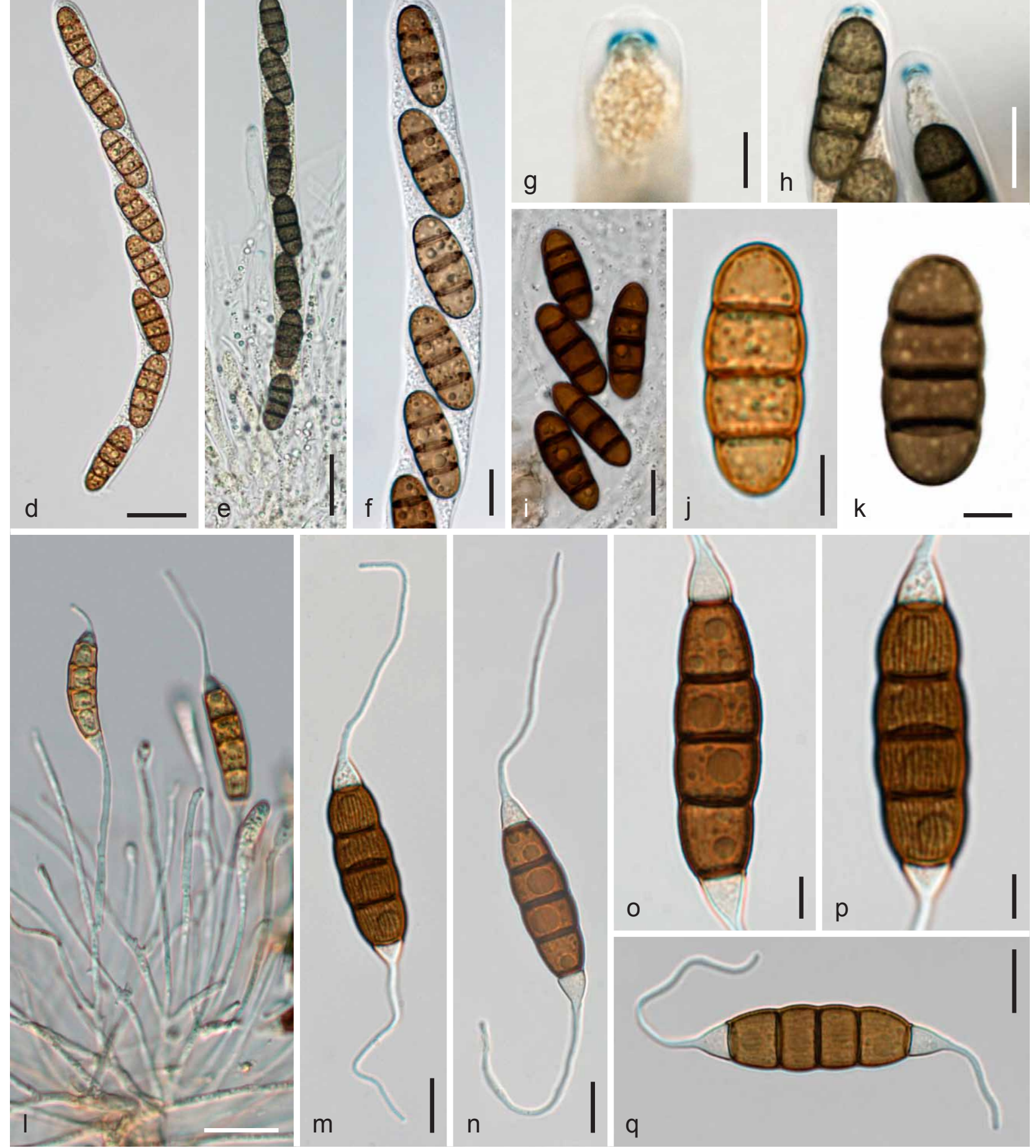

Fig. 10 Seiridium marginatum (WU 33575). a. Ascomata in bark fissure; b. ascoma in face view; c. conidioma in face view; d-f. asci (e. in Lugol; f. upper part with thickened apex); $\mathrm{g}$, h. ascus apex in Lugol; i-k. ascospores (i. in $3 \% \mathrm{KOH}$; $\mathrm{k}$. in Lugol; note the pitted surface); I. conidiophores; $\mathrm{m}-\mathrm{q}$. conidia (o, p. detail in section and surface view). - Scale bars: $a-c=0.3 \mathrm{~mm} ; \mathrm{d}, \mathrm{e}, \mathrm{I}=20 \mu \mathrm{m} ; \mathrm{f}, \mathrm{h}, \mathrm{i}, \mathrm{m}, \mathrm{n}, \mathrm{q}=10 \mu \mathrm{m} ; \mathrm{g}, \mathrm{j}, \mathrm{k}, \mathrm{o}, \mathrm{p}=5 \mu \mathrm{m}$. 
globose to pyriform, $0.3-0.6 \times 0.2-0.5 \mathrm{~mm}$, scattered or confluent in numbers of 2-3; peridium 20-30 $\mu$ m thick, dark brown, pseudoparenchymatous. Ostioles central, slightly papillate, black, circular in section, periphysate. Paraphyses filiform, $1.5-2 \mu \mathrm{m}$ wide at the free apex, widening to $4.5 \mu \mathrm{m}$ downwards. Asci cylindrical, (145-)150-178(-190) × (9.0-)10.5-14.8(-16) $\mu \mathrm{m}(\mathrm{n}=10)$, containing 8 (obliquely) uniseriate ascospores, unitunicate, thin-walled, with a knob-like base and crozier and a slightly thickened apex containing an amyloid ring (3.2-)3.54.5(-4.8) $\mu \mathrm{m}$ wide, $(0.6-) 0.9-1.6(-1.8) \mu \mathrm{m}$ high $(\mathrm{n}=21)$. Ascospores (17.5-)21-25.7(-32.5) × (8.0-)8.5-10(-11.5) $\mu \mathrm{m}, \mathrm{I} / \mathrm{w}(2.1-) 2.3-2.8(-3.7)(\mathrm{n}=56)$, cylindrical-oblong, with 3 , rarely 5 thick eusepta often thicker than the wall, yellow- to dark brown, darkening in $\mathrm{KOH}$ and Lugol, multiguttulate when fresh and often with irregularly disposed minute light dots $0.5-1 \mu \mathrm{m}$ diam. Conidiomata on the natural host acervular but often with a narrow opening, depressed globose, 0.3-0.6 $\mathrm{mm}$ diam, 0.2-0.4 $\mathrm{mm}$ high, immersed-erumpent, dehiscent by irregular crumbling, scattered or confluent, dark grey to black. Basal wall pseudoparenchymatous, of small dark brown cells. Conidiophores hyaline, cylindrical, more or less straight, sparsely and mostly asymmetrically branched near the base, up to c. $90 \times 4 \mu \mathrm{m}$, branches up to $60 \mu \mathrm{m}$ long. Conidia formed terminally, (35.2-)38.2-42(-45) × (8.2-)8.8-10.2(-11) $\mu \mathrm{m}$, I/w (3.5-)3.9-4.6(-4.9) ( $n=51)$, fusiform, straight, with 5 thick, scarcely constricted eusepta, versicolorous, of 4 brown cells (24.5-35) $\mu \mathrm{m}$ long, with striate surface and hyaline end cells, each with a hyaline unbranched filiform appendage to $52 \mu \mathrm{m}$ long.

Habitat - In bark of Rosa canina.

Distribution - Europe (France, Germany, Switzerland).

Additional material examined. AustrIA, Niederösterreich, Hardegg, Maxplateau, on twigs of Rosa canina, 27 Apr. 2015, H. Voglmayr (WU 33576, culture SEI1 = CBS 140404).

Notes - A detailed description of the sexual morph was given by Shoemaker \& Leclair (1975); see also Fuckel (1874) under Massaria marginata. Although Seiridium marginatum is morphologically well-defined, its host genus is extremely diverse and distributed all over the world. Therefore, it cannot be ruled out that morphologically similar but phylogenetically deviating species may appear in future. For this reason we fix the application of the name via epitypification.

\section{Strickeria Körb., Parerga Lichenol. (Breslau) 5: 400. 1865}

Type species. Strickeria kochii Körb.

Strickeria was originally described as a genus of lichenised fungi (Körber 1865). Since then this generic name was used by several authors for some Dothideomycetes with brown muriform ascospores, often with Teichospora in synonymy (Winter 1887) or Strickeria as a synonym of Teichospora. Barr (1990a, b), however, treated them as distinct genera of Dothideomycetes. Eriksson (in Eriksson \& Hawksworth 1991), upon examination of original material of $S$. kochii, determined that the asci are unitunicate and therefore Strickeria was classified as Sordariomycetes incertae sedis (Lumbsch \& Huhndorf 2010) or Ascomycetes (Kirk et al. 2008). We show here that Eriksson's observation was correct and determine the phylogenetic relationship of S. kochii in Xylariales.

Strickeria kochii Körb., Parerga Lichenol. (Breslau) 5: 400. 1865 - Fig. 11

= Teichospora pezizoides Sacc. \& Speg., Michelia 1(no. 3): 350 (1878).

= Hendersonia fusarioides Sacc., Michelia 1: 213 (1878).

三 Scolicosporium pauciseptatum Constant., Mycotaxon 41(2): 467 (1991).
Lectotype, here designated: AustRIA, Oberösterreich, Kremsmünster, on bark of Robinia pseudoacacia, 1862, Clar. Poetsch, in Koerber, Lich. Sel. Germ. 264 (W 1915-11805!; MBT202961). Epitype, here designated due to the earlier confusion with genera of Dothideomycetes: AustRIA, Vienna, 22nd district, Lobau, near Panozzalacke, on bark of Robinia pseudoacacia, 7 Mar. 2015, W. Jaklitsch (WU 33571; MBT202962; ex-epitype culture CBS $140411=\mathrm{C} 143)$

Ascomata superficial, scattered, (110-)170-260(-315) $\mu \mathrm{m}$ diam $(n=20)$, first nearly globose, soon collapsing, discoid, cupulate or turbinate with circular outline, broadly attached or downward slightly attenuated (broadly turbinate); surface black, warted, peridium thick and hard, dark brown, pseudoparenchymatous. Apex often with a short central, 45-80 $\mu \mathrm{m}$ wide papilla, roundish, angular to slightly elongate, ostiole periphysate. Hamathecium of simple, 1.5-4.5 $\mu \mathrm{m}$ wide, apically free paraphyses. Asci (106-)110-129(-132) × (11-)11.5-13(-13.5) $\mu \mathrm{m}(\mathrm{n}=10)$, cylindrical, with 8 uniseriate ascospores, short stipe and thickened apex without a distinct discharge apparatus, in $\mathrm{KOH}$ ascus wall thicker, ocular chamber larger, sometimes branched (thickened apex indented). Ascospores (12-)14.8-19(-24.2) $\times(6.0-) 6.5-7.8(-8.5) \mu \mathrm{m}, \mathrm{I} / \mathrm{w}(1.7-) 2.1-2.7(-3.3)(\mathrm{n}=72)$, ellipsoid or broadly fusiform, with 3 transverse non-constricted septa and 1 longitudinal septum in mid cells, brown, with (sub-) hyaline end cells, smooth.

Asexual morph in nature: Ascomata associated with minute black pycnidia, 70-105 $\mu \mathrm{m}$ diam, globose, warted, with central pore. Pycnidial wall pseudoparenchymatous, of dark brown angular to globose cells 5-13 $\mu \mathrm{m}$ diam. Conidiophores 1-3celled, hyaline, simple, to c. $40 \mu \mathrm{m}$ long. No phialides present. Conidia formed in fascicles, (23.5-)32.5-48.3(-51) $\times(4.7-)$ $5.0-6.0(-6.3) \mu \mathrm{m}, \mathrm{I} / \mathrm{w}(4.4-) 6.0-8.8(-9.6)(\mathrm{n}=21)$, falcate, first hyaline, 1-celled, finally brown, with 3-4 non-constricted septa, thin-walled, mid cells cylindrical, end cells lighter, acute and curved.

Asexual morph in culture: Colonies on $\mathrm{CMD}$ at $22^{\circ} \mathrm{C}$ reaching after $1 \mathrm{mo}$ a radius of up to c. $45 \mathrm{~mm}$, hyaline to whitish, dense, slightly zonate, centre turning brown due to minute dark dots; the latter developing to pycnidia after c. 2 weeks. Pycnidia 70-175 $\mu \mathrm{m}$ diam, globose to cylindrical, dark brown, smooth, containing short hyaline cylindrical conidiophores producing strongly curved falcate conidia $35-49 \times 4.7-6.0 \mu \mathrm{m}$ of $2-5$ cylindrical to nearly globose brown mid cells, a subhyaline, acute end cell and a subhyaline cylindrical base cell.

Habitat - On bark, particularly in recessed regions of thick bark of living trunks of Robinia pseudoacacia.

Distribution — Europe (Austria, Germany, Italy).

Additional material examined (all from bark of standing trees of Robinia pseudoacacia). AustRIA, Niederösterreich, Gumpoldskirchen, from Melkerhof upward, 1 Mar. 2015, W. Jaklitsch \& H. VogImayr (WU 33570, culture C138); Manhartsbrunn, 8 Mar. 2015, W. Jaklitsch \& H. Voglmayr (WU 33572, culture C146); Mannersdorf im Leithagebirge, Schweingraben, 14 Mar. 2015, H. Voglmayr \& I. Greilhuber (WU 33573, culture C149); Mödling, Eichkogel, 19 Apr. 2015, W. Jaklitsch \& H. Voglmayr (WU 33574). - ITALY, Tuscany, Florence, Tavarnuzze, roadside, close to the motorway A1, 29 Oct. 2015, W. Jaklitsch (WU 36856).

Notes - Maturation of asci of Strickeria kochii in nature is asynchronous and due to the habitat-related exposition of the ascomata to drought many asci are not optimally developed or overmature in most specimens. Often they contain aberrant ascospores, with up to 8 septa and up to $33 \times 7 \mu \mathrm{m}$.

Teichospora pezizoides and Hendersonia fusarioides, which were also described from Robinia, are evidently synonymous with Strickeria kochii; for a description and illustrations of $H$. fusarioides (as Scolicosporium pauciseptatum) see Constaninescu (1991). 

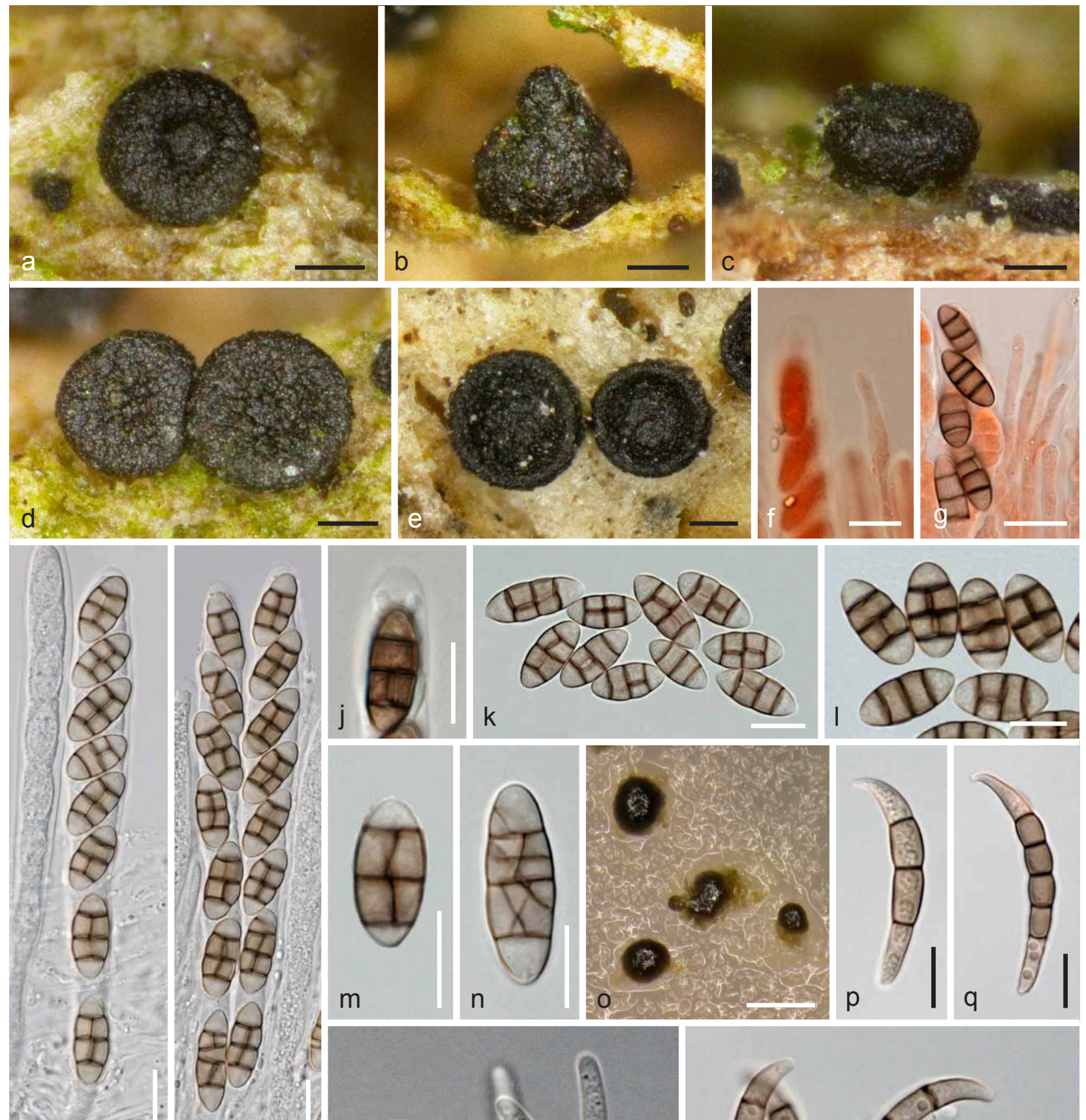

h
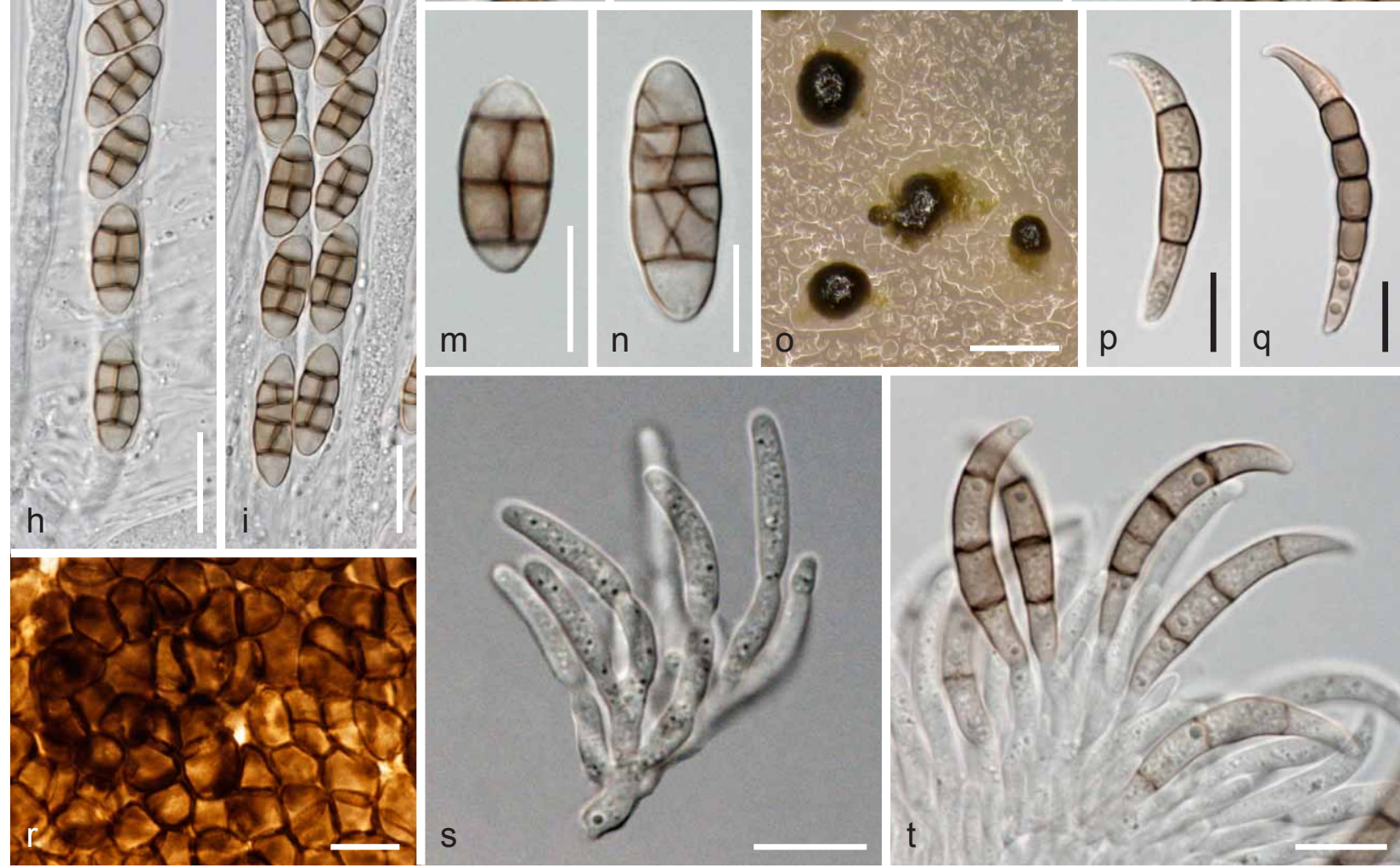

Fig. 11 Strickeria kochii. a-e. Ascomata (b, c. in side view); f, g. free apical ends of paraphyses in Congo Red; h, i. asci; j. ascus apex; k-n. ascospores; o-q. asexual morph in culture (CMD, $17-24 \mathrm{~d}, 22{ }^{\circ} \mathrm{C}$ ); o. pycnidia; $\mathrm{p}$, q. conidia; $r-t$. asexual morph from the natural substrate (r. pycnidial wall; s, t. conidiophores and conidia) (a, b, d: WU 33572; e, m, n: lectotype W 1915-11805; p, q: WU 33570; c, f-l, o, r-t: WU 33571). - Scale bars: a-e = 100 4m; f, j-n, $\mathrm{p}-\mathrm{t}=10 \mu \mathrm{m} ; \mathrm{g}-\mathrm{i}=15 \mu \mathrm{m} ; \mathrm{o}=150 \mu \mathrm{m}$. 
Xylariaceae Tul. \& C. Tul. 1863

Clypeosphaeria Fuckel, Jahrb. Nassauischen Vereins Naturk. 23-24: 117 (1870) [1869-70]

Type species. Clypeosphaeria notarisii Fuckel (a synonym of C. mamillana (Fr.) Lambotte).

Clypeosphaeria is characterised by ascomata with a conspicuous clypeus and brown, oblong, 1-celled ascospores with 3 indistinct pseudosepta and without a germ slit (Munk 1957). Barr (1989) extended the generic concept to include species without pseudosepta, but it is doubtful that the two other species recognised in Clypeosphaeria by Barr (1989), C. perfidiosa and C. americana, are congeneric with C. mamillana, the current name of $C$. notarisii.

\section{Clypeosphaeria mamillana (Fr.) Lambotte, FI. Mycol. Belgique} (Verviers) 2: 247. 1880 - Fig. 12 1818.

Basionym. Sphaeria mamillana Fr., Kongl. Vetensk. Acad. Handl. 39: 103.

= Clypeosphaeria notarisii Fuckel, Jahrb. Nassauischen Vereins Naturk. 23-24: 117. 1870 [1869-70].

For additional synonyms, see Barr (1989).

Typification. Lectotype of Sphaeria mamillana, here designated: FRANCE, on Cornus sanguinea (C. alba, according to branch colour), Herb. Guepin (UPS F-175463!; MBT202963). Epitype of Sphaeria mamillana, here designated: France, 21, Dijon, Rue de Malines, on branches of Cornus alba, 28 Aug. 2015, A. Gardiennet AG15060 (WU 33598; MBT202964; ex-epitype culture CLM = CBS 140735). Lectotype of Clypeosphaeria notarisii, here designated: Germany, Oestrich, Oestricher Wald, on branches of Rubus fruticosus, without date, L. Fuckel, Fungi Rhen. Exs. 1823 (W 2015-04170!; MBT203104)

Ascomata perithecial, immersed in a distinct clypeate stroma, with a black clypeus $0.5-1.2 \mathrm{~mm}$ diam and a central apical papilla, scattered to densely aggregated with confluent clypei, depressed globose to ellipsoid, 400-600 $\mu \mathrm{m}$ diam, circular in transverse section. Apical papilla distinct, black, 50-90 $\mu \mathrm{m}$ diam, commonly surrounded by a lighter coloured zone. Peridium 15-25 $\mu \mathrm{m}$ wide, blackish brown above, lighter brown at the base. Hamathecium of apically free, sparsely branched, 1.3-4 $\mu \mathrm{m}$ wide paraphyses similarly long as the asci. Asci in $3 \% \mathrm{KOH}(139-) 150-174(-181) \times(6.5-) 7.5-10.5(-12)$ $\mu \mathrm{m}(\mathrm{n}=15)$, unitunicate, cylindrical, with 8 (partly obliquely) uniseriate, rarely more or less biseriate ascospores, with a short stipe; apex containing a wedge-shaped amyloid apical ring (2.2-)2.5-2.8(-3.0) × (2.3-)2.5-3.2(-3.5) $\mu \mathrm{m}(\mathrm{n}=21)$. Ascospores (13.7-)17.8-21.5(-25.2) × (4.6-)5.3-6.2(-7.2) $\mu \mathrm{m}, \mathrm{I} / \mathrm{w}(2.2-) 3.1-3.8(-4.4)(\mathrm{n}=232)$, ellipsoid, oblong to fusiform, commonly slightly curved, with subacute to rounded ends, light to dark brown, 1-celled and when vital with 3 indistinct pseudosepta and few small guttules, when dead cytoplasma separating from the concave side and forming 4 compartments at the other side, in $3 \% \mathrm{KOH}$ pseudosepta becoming faint to invisible. Colonies on MEA and CMD hyaline to pure white, dense, radial, growth radius at $22{ }^{\circ} \mathrm{C}$ after $1 \mathrm{mo}$ to c. $50 \mathrm{~mm}$ on CMD, to c. $40 \mathrm{~mm}$ on MEA. No asexual morph observed.

Habitat - In bark of various shrubs and herbaceous plants; e.g. on Cornus (type host of S. mamillana), especially C. alba including its cultivars; Rubus fruticosus (type host of $C$. notarisii); Epilobium spp.

Distribution - Europe, probably North America.

Additional material examined. FRANCE, 21, Saint-Apollinaire, D700, L'Arc, on branches of Cornus alba, 28 Aug. 2015, A. Gardiennet AG15061 (WU 33599, culture CLM1); Marcille-sur-Tille, Grand rue, on branches of Cornus alba, 19 Aug. 2015, A. Gardiennet AG15056 (WU 36850, culture CLM2); Marcille-sur-Tille, Rue de Messageries, on branches of Cornus alba, 19 Aug. 2015, A. Gardiennet AG15059 (WU 36851). - GermanY, Steinberg, on branches of Rubus fruticosus, spring, without date, L. Fuckel, Nassau's
Flora, ex Herb. Barbey-Boissier (W 1904-3852); Oestrich, Oestricher Wald, Mappen, on branches of Rubus fruticosus, winter, without date, L. Fuckel, Herbier Fuckel 1894 ex Herb. Barbey-Boissier (W 1922-11835).

Notes - We treat Clypeosphaeria mamillana here as it is the type of Clypeosphaeriaceae, which has not been included in recent molecular phylogenies. The generic type, Clypeosphaeria notarisii, is generally accepted to be synonymous with C. mamillana, which has priority (for details see Barr 1989). A Guepin specimen of Sphaeria mamillana ex Herb. Fries, which is here designated as lectotype, was examined and documented; its ascospore size (20.2-24.8 $\times 5-6.2 \mu \mathrm{m})$ and septation perfectly fit recent French collections of the species. To stabilise the nomenclature, the recent collection WU 33598, which also originates from France and for which a culture and sequences are available, is here designated as epitype of Sphaeria mamillana. Our investigations of material of C. notarisii collected by Fuckel revealed identical ascospore size and septation, confirming synonymy of Clypeosphaeria notarisii with C. mamillana. The specimen of Fuckel's Fungi Rhenani 1823 (mentioned in the protologue) preserved in $\mathrm{W}$ is here designated as lectotype of $C$. notarisii. Upon colonisation by Clypeosphaeria, the small branches of Cornus alba and Rubus fruticosus are usually cleared, becoming light brown to whitish, and ascomata are then easy to spot. Barr (1989) reported occasional occurrence of a basal euseptum and small germ pores or slits at the ends of the ascospores, which could not be observed in our investigations. Our phylogenetic analyses places C. mamillana in Xylariaceae (Fig. 1), and classification in a separate family Clypeosphaeriaceae is therefore unjustified.

Clypeosphaeria uniseptata, included as representative of Clypeosphaeriaceae by Senanayake et al. (2015), is not congeneric with Clypeosphaeria but belongs to Lepteutypa (see above).

\section{Xylariales Nannf. 1932 inc. sed.}

\section{Basiseptospora Jaklitsch \& Voglmayr, gen. nov. - MycoBank MB814844}

Etymology. Referring to the basal ascospore septum.

Type species. Basiseptospora fallax (Petr.) Jaklitsch \& VogImayr.

Genus of Xylariales. Perithecia small, immersed in host bark below pallid to brownish patches, scattered, depressed globose, hyaline to yellowish, with a (sub-)hyaline pseudoparenchymatous peridium of thin-walled cells, outermost peridial cell layer becoming brownish with age. Hamathecium of apically free, septate paraphyses embedded in gel. Asci fusoid to clavate, octosporous, unstable when fresh, apex containing an amyloid ring. Ascospores distinctly apiosporous with a small lower cell, straight or slightly curved, surrounded by a gelatinous sheath swelling in $3 \% \mathrm{KOH}$. Asexual morph not known.

Notes - Basiseptospora differs from the unrelated genus Pseudomassaria primarily in its pallid peridium. The phylogenetic relationship to Polyancora, a genus with peculiar condial morphology and ecology (Voglmayr \& Yule 2006), is highly supported in ML bootstrap analyses, but receives no significant bootstrap support in MP analyses. The familial affiliation of Basiseptospora is currently unresolved, and we refrain from describing a new family due to lack of significant backbone support of the deeper nodes of the phylogenetic trees.

\section{Basiseptospora fallax (Petr.) Jaklitsch \& Voglmayr, comb.} nov. - MycoBank MB814845

Basionym. Apiosporina fallax Petr., Ann. Mycol. 25, 3/4: 279. 1927. 三 Pseudapiospora fallax (Petr.) Petr., Hedwigia 68: 233. 1928.

三 Pseudomassaria fallax (Petr.)Arx, Ber. Schweiz. Bot. Ges. 62: 349. 1952. 

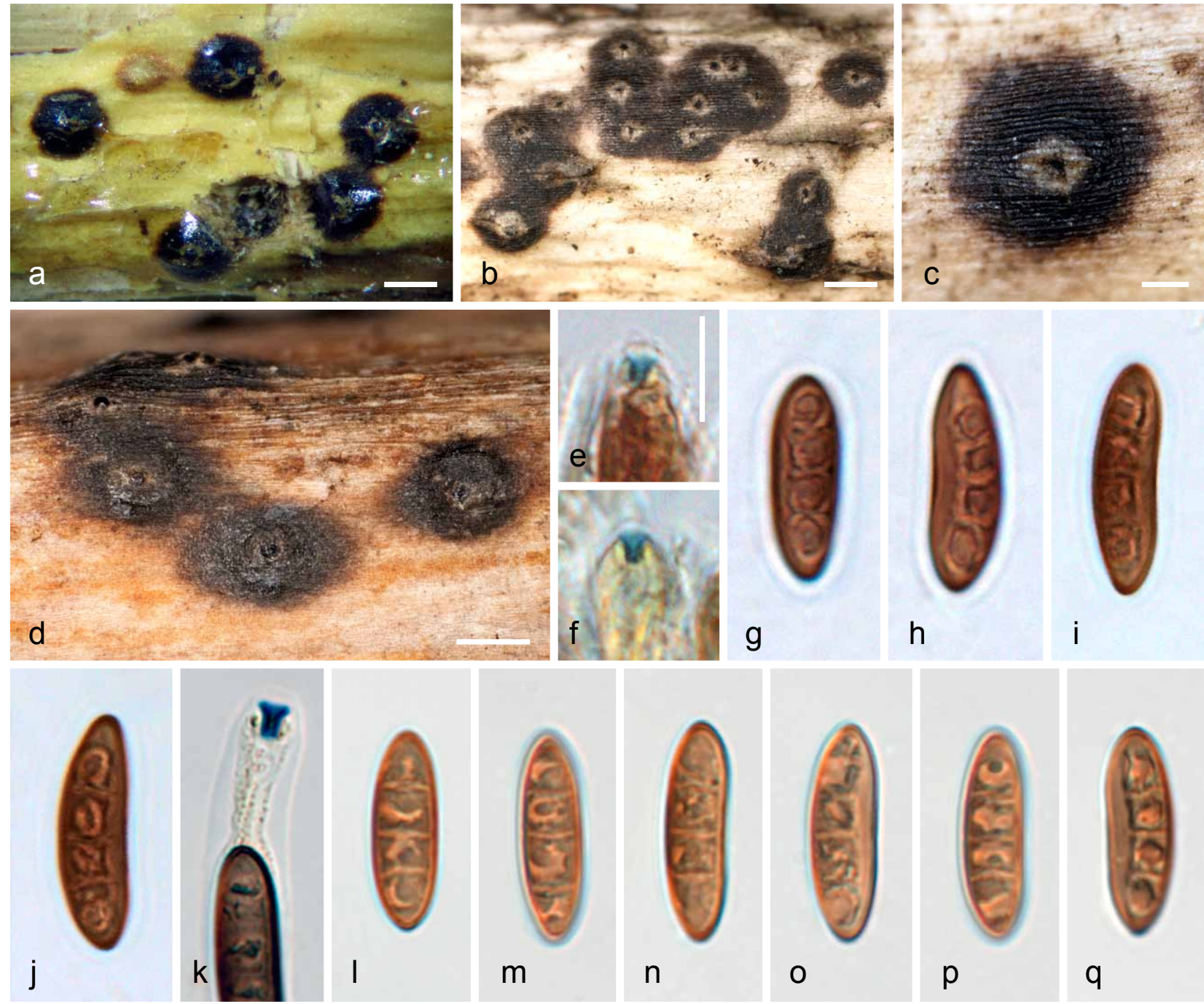

g

$\mathrm{h}$

i

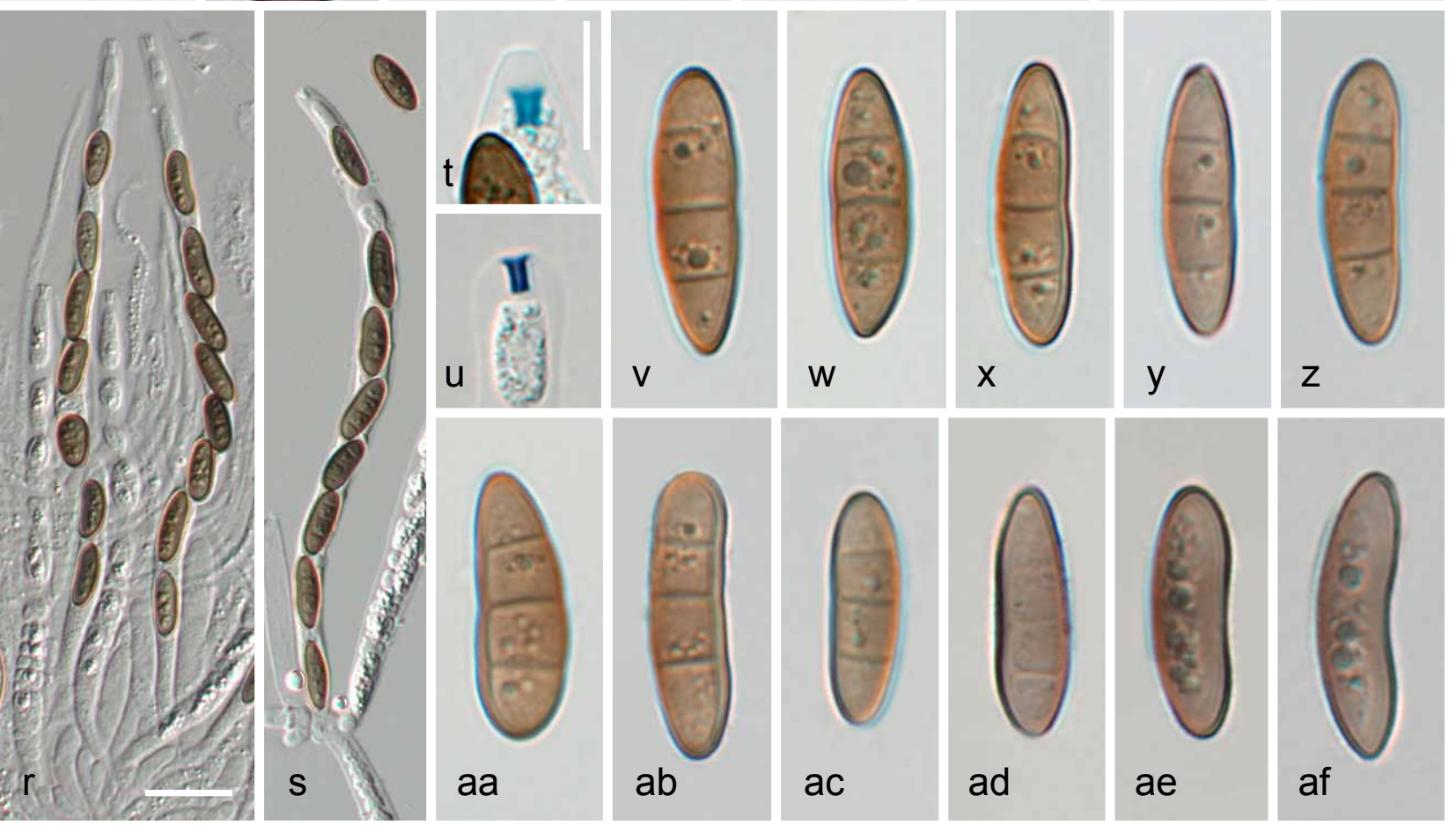

Fig. 12 Clypeosphaeria mamillana. a-g. Ascomata in face view embedded in cleared host tissue, showing the clypeus and ostiole; e, f, k, t, u. ascus apices (e, f, t. in Lugol; k, u. in $3 \% \mathrm{KOH}+$ Lugol); g-j, I-q, v-af. ascospores, note the three pseudosepta disappearing in $3 \% \mathrm{KOH}$ (ad-af) and the plasma separating from the concave side of dead ascospores ( $\mathrm{h}-\mathrm{j}, \mathrm{o}, \mathrm{q})$; r, s. asci with filiform paraphyses (in $3 \% \mathrm{KOH}$ ) (a, e-j: UPS F-175463 (lectotype of Sphaeria mamillana; images by I. Olariaga); b, c, r-s, ad-af: WU 33598 (epitype of Sphaeria mamillana); d, k-q: Fuckel, Fungi Rhenani 1823 (W 2015-04170, lectotype of Clypeosphaeria notarisii); t-ac: WU 33599). - Scale bars: a, b, d = $0.5 \mathrm{~mm} ; \mathrm{c}=0.2 \mathrm{~mm}$; $\mathrm{e}-\mathrm{q}, \mathrm{t}-\mathrm{af}=10 \mu \mathrm{m} ; \mathrm{r}, \mathrm{s}=20 \mu \mathrm{m}$. 
Typification. Lectotype of Apiosporina fallax, here designated: $\mathrm{CzECH}$ Republic, Moravia, Hranice (Mährisch-Weißkirchen), shrubs at the margin of the common pasture of Velká (Welka), on dead twigs of Cornus sanguinea, Oct. 1926, F. Petrak (W 1978-0010762; MBT203101); same collection data (W 1992-0005924, isotype). Epitype, here designated: AusTRIA, Vienna, 3rd district, Botanical Garden of the University, on corticated twigs of Cornus sanguinea, 9 Jan. 2011, H. Voglmayr (WU 31326, ex-epitype culture CBS 129020 = PSC; MBT203102; ITS-LSU sequence JF440983).

Notes - This species has been described and illustrated as Pseudomassaria fallax in detail by Jaklitsch \& Voglmayr (2012). Two collections are mentioned in the protologue, and of the first of these, two specimens are extant in W, one of which is here selected as lectotype. To stabilise the nomenclature, the recent collection WU 31326, which was illustrated in Jaklitsch \& Voglmayr (2012) and for which a culture and sequences are available, is here designated as epitype.

\section{DISCUSSION}

All genera treated here in detail are represented by their type species, which were recently collected, cultured and sequenced. This enabled us to determine their phylogenetic relationships and thus several taxonomic and nomenclatural conclusions can be drawn on the generic or higher levels. Quite unexpectedly Requienella and the Requienellaceae belong to the Xylariales despite their clearly fissitunicate asci. Although this may be surprising, fissitunicate dehiscence of asci has been also noted in other groups of Sordariomycetes, such as the Diaporthales, e.g. in sexual morphs of Stegonsporium (see Voglmayr \& Jaklitsch 2008 under Prosthecium, Voglmayr \& Jaklitsch 2014) or in the Calosphaeriales (Damm et al. 2008). We also show that earlier opinions about synonymy in Requienella are erroneous: two different species, $R$. seminuda and $R$. fraxini, whose differences are corroborated by rpb2 and tef1 sequences, occur on Olea and Fraxinus. Acrocordiella occulta is even generically different from Requienella.

In recent publications on xylarialean fungi several new families were described, also the order Amphisphaeriales was revived by Senanayake et al. (2015). In our analysis approximately the upper third of the phylogenetic tree (Fig. 1) forms a statistically highly supported clade, which, however, does not include Amphisphaeria and is thus not congruent with the Amphisphaeriales. We name this clade after the earliest available name, Sporocadaceae with Robillardaceae (Crous et al. 2015) as a synonym. Also the families Bartaliniaceae, Discosiaceae and Pestalotiopsidaceae of Senanayake et al. (2015) are relegated to synonymy. In lack of other markers for the great majority of taxa the current phylogenies of Xylariales are primarily based on rDNA sequence data, and resolution of these phylogenies is simply insufficient to allow far-reaching subdivisions into formal higher taxa (Fig. 1). A subgrouping also appears inappropriate, because the Sporocadaceae obviously represent a natural grouping, which has the following common basis: (most) asexual morph genera are acervular coelomycetes with the same type of conidiogenesis and conidium, the latter only differing in colour (hyaline, pale or dark brown), septation (phragmo- or dictyosporous) and the number, orientation and type of appendages (exogenous/cellular or endogenous/cell elongation, branched/unbranched). As Sutton (1980: 265) pointed out, genera were either lumped (Guba 1961) or split in a large number of genera (Steyaert 1949 and later publications), in part illogically, as most genera are defined by conidial septation and numbers of appendages, whereas there is no such splitting in Seimatosporium. A subsequent splitting of Seimatosporium into five genera (Nag Raj 1991) was disproven by Tanaka et al. (2011). In any case, the definition and delimitation of genera but also species is far from clear, and molecular data of type species are lacking for many genera. Genera and species had been defined based on dried herbarium specimens, but conidial traits are much more variable in culture. Sutton (1980) also noted that the complex containing Monochaetia, Morinia, Pestalotia, Pestalotiopsis, Seimatosporium, Seiridium and Truncatella is a well-defined group. This group, augmented by Discosia s.l., is highly supported in our analyses and named Sporocadaceae as noted above. Strickeria kochii falls in a subclade of this group, which is no surprise when the asexual morph is considered. In any case, our result confirms Eriksson's (Eriksson \& Hawksworth 1991) view that the genus Strickeria belongs to the Sordariomycetes and is thus unavailable for Dothideomycetes that had been segregated from Teichospora. Lepteutypa hippophaës, for which Shoemaker \& Müller (1965) found a monochaetia-like asexual morph (due to its 4-septate conidia) in culture and which is member of another subclade of the Sporocadaceae, is segregated from Lepteutypa and placed in Hymenopleella under the new name $H$. hippophaëicola. Much more sampling is necessary to evaluate different taxonomic approaches. In our opinion currently too much splitting is going on and too many family names are being created, for phylogenetic clades, which are statistically poorly supported and may change, when more data become available. Our phylogenetic characterisation of the generic types of Lepteutypa, L. fuckelii, and Seiridium, S. marginatum, clearly shows that these genera are unrelated and thus earlier views of congenericity are erroneous. A good taxonomy of these fungi, esp. Seiridium spp., is phytopathologically relevant, as important diseases like cypress canker (or 'Seiridium canker of Cupressus'; see e.g. Krokene et al. 2004) are known. Lepteutypa fuckelii does not form an asexual morph, but asexual morphs have been described for several species assigned to Lepteutypa, often by association on the natural host: e.g. Seiridium canariense for Lepteutypa cisticola (Nag Raj \& Kendrick 1985), S. cardinale, S. cupressi and S. unicorne for L. cupressi (Swart 1973, Nag Raj \& Kendrick 1985) or Pestalotiopsis sp. for L. podocarpi (Van der Aa 1986). These species are likely not congeneric with L. fuckelii. For Lepteutypa cupressi this is shown in the present work (Fig. 1). This species was described from Cupressus macrocarpa in Kenya as Rhynchosphaeria cupressi (syn. Cryptostictis cupressi). Sequences deposited in GenBank are from the strain IMI 052255, also from Kenya, but Cupressus forbesii (Hesperocyparis forbesii) is given as host in the CABI database. This may represent Lepteutypa cupressi, but is probably not conspecific with isolates of Seiridium cupressi from Australia (Cunnington 2007), South Africa and New Zealand (Barnes et al. 2001). Although Swart (1973) interpreted the high morphological variation of Seiridium on Cupressus only as variants of a single species, Barnes et al. (2001) separated $S$. cardinale, S. cupressi and S. unicorne as distinct species using histone and tubulin sequences and determined that the major pathogens are $S$. cardinale and $S$. cupressi. Cunnington (2007) correlated tubulin sequences with conidial morphology and determined S. cupressi as the common cause of cypress canker in south-eastern Australia. He also maintained that the sexual morph of S. cupressi is Lepteutypa cupressi, and that the sexual morphs of the other Seiridium species are not known. However, there is still no evidence of a direct molecular connection of the African L. cupressi and the Australian S. cupressi and its sexual morph. Unfortunately, no African material of the sexual morph, Lepteutypa cupressi, was included in these analyses, and no histone and tubulin sequences are yet available for the African L. cupressi. For the strain ATCC 48158 of $S$. cupressi originating from New Zealand, ITS as well as histone and tubulin sequences are available. In the phylogenetic analyses of Barnes et al. (2001) and Cunnington (2007), this strain is contained within the $S$. cupressi clade. However, in our 
phylogenetic analyses based on ITS (Fig. 1), S. cupressi strain ATCC 48158 is distinct from L. cupressi IMI 052255, indicating that they are not conspecific. If this is the case, it may have the undesirable consequence that the current species concept of $S$. cupressi is inappropriate, as both $S$. cupressi and L. cupressi are based on material from the same hosts collected in Kenya. This group therefore requires substantial taxonomic revision, including a representative sampling of well-identified strains as well as additional sequence regions other than ITS-LSU. In conclusion Lepteutypa had been ill-defined and it was wise to recognise genera like Ellurema (Nag Raj \& Kendrick 1985) or Pestalosphaeria (Barr 1975), which belong to the Sporocadaceae. On the other hand Seiridium was treated as a synonym of Monochaetia (see Sutton 1980), until Shoemaker et al. (1966) resurrected the genus. It is still unclear whether these genera should be recognised as separate entities.

Clypeosphaeria uniseptata, a non-type species was taken as the basis of the Clypeosphaeriaceae (Hernández-Restrepo et al. 2015, Senanayake et al. 2015). Here we combine this species in Lepteutypa. As a consequence, the concept of the Clypeosphaeriaceae as based on C. uniseptata in Senanayake et al. (2015) is erroneous, because it is not closely related to the generic type, Clypeosphaeria mamillana (Fig. 1), and we do not recognise a family Clypeosphaeriaceae. DNA data of fresh material of $C$. mamillana clearly place the fungus and thus the genus Clypeosphaeria in the Xylariaceae. This position was also found for the GenBank ITS accession AF009808 labelled Clypeosphaeria mamillana (not shown), but this sequence is different from ours, suggesting a different species of Clypeosphaeria.

As a continuation of our previous study on Pseudomassaria (Jaklitsch \& Voglmayr 2012), we also evaluated the phylogenetic relationships of Pseudomassaria corni, $P$ carolinensis and $P$. fallax, and new materials as well as extended sequence data and phylogenies called for implementing necessary taxonomic changes. In the ML tree (Fig. 1), the newly included $P$. corni is sister species to Pseudomassaria; however, this position was usually not supported in MP analyses, which mostly revealed an unsupported sister group relationship to Leiosphaerella (data not shown). We are therefore using the already available genus Pseudapiospora for P. corni, of which it is the generic type. The septum of its ascospores is much closer to the middle of the ascospore than in species of Pseudomassaria, which may be another argument for its classification in Pseudapiospora. In agreement with previous studies (Shirouzu et al. 2010, Jaklitsch \& Voglmayr 2012), Pseudomassaria carolinensis is contained within the genus Beltraniella (Beltraniellaceae) with high support (Fig. 1). However, its ITS sequence is distinct from $B$. portoricensis, which was tentatively given as asexual morph by Hodges \& Barr (1971), although they already noticed some morphological and ecological differences. Acknowledging these differences, it is here combined in Beltraniella. For $P$. fallax, also phylogenetically distant from $P$ seudomassaria, the new genus Basiseptospora is described.

Last but not least, we provide sequences of Broomella vitalbae, Cainia desmazieri and Creosphaeria sassafras. Broomella vitalbae is revealed as a close relative of the generic type of Truncatella, T. angustata (syn. T. truncata). Based on priority, the generic name Broomella should be applied. Cainia desmazieri is confirmed to be closely related to the generic type, Cainia graminis, which is corroborated by similar morphology. Creosphaeria sassafras is sister genus to Lopadostoma, which is in line with Senanayake et al. (2015).
Acknowledgements We thank the fungarium curators of $B, G, G Z U, W$ and Walter Till at WU for sending and managing collections, the staff at $L$ for access to Persoon's material, I. Olariaga for the examination and imaging of UPS specimens, A. Igersheim for information on specimens in W, H.-O. Baral, P. Bormans, P. Cannon, J. Fournier, G. Friebes, T. Læssøe, B. Norden, K. Preston-Mafham, T. Richter, E. Rubio, P. Thompson and B. Wergen for fresh material and/or data and B. Aguirre-Hudson (K) for information about the types of Sphaeria corni and Seiridium marginatum. The financial support by the Austrian Science Fund (FWF; project P25870-B16) is gratefully acknowledged.

\section{REFERENCES}

Aptroot A. 1991. A monograph of the Pyrenulaceae (excluding Anthracothecium and Pyrenula) and the Requienellaceae, with notes on the Pleomassariaceae, the Trypetheliaceae and Mycomicrothelia. Bibliotheca Lichenologica 44: 1-178.

Barnes I, Roux J, Wingfield MJ, et al. 2001. Characterization of Seiridium spp. associated with cypress canker based on ß-tubulin and histone sequences. Plant Disease 85: 317-321.

Barr ME. 1964. The genus Pseudomassaria in North America. Mycologia 56: 841-862.

Barr ME. 1975. Pestalosphaeria, a new genus in the Amphisphaeriaceae. Mycologia 67: 187-194.

Barr ME. 1989. Clypeosphaeria and the Clypeosphaeriaceae. Systema Ascomycetum 8: 1-8.

Barr ME. 1990a. Some dictyosporous genera and species of Pleosporales in North America. Memoirs of the New York Botanical Garden 62: 1-92.

Barr ME. 1990b. Melanommatales (Loculoascomycetes). North American Flora. Series II, 13: 1-129.

Boise JR. 1986. Requienellaceae, a new family of Loculoascomycetes. Mycologia 78: 37-41.

Carbone I, Kohn LM. 1999. A method for designing primer sets for speciation studies in filamentous ascomycetes. Mycologia 91: 553-556.

Castañeda Ruiz RF, Cano J, Guarro J. 1996. Notes on conidial fungi. VII. Two new species of Beltraniella from Cuba. Mycotaxon 58: 243-251.

Constantinescu O. 1991. Scolicosporium pauciseptatum nom. nov. Mycotaxon 41: 467-470.

Corlett M. 1978. Pseudomassaria corni. Fungi Canadenses No. 121. National Mycological Herbarium, Agriculture Canada, Ottawa, Ontario (available online at the CBS).

Corlett M. 1981. A taxonomic survey of some species of Didymella and Didymella-like species. Canadian Journal of Botany 59: 2016-2042.

Crous PW, Carris LM, Giraldo A, et al. 2015. The genera of fungi - fixing the application of the type species of generic names - G 2: Allantophomopsis, Latorua, Macrodiplodiopsis, Macrohilum, Milospium, Protostegia, Pyricularia, Robillarda, Rutola, Septoriella, Torula, and Wojnowicia. IMA Fungus 6: 163-198.

Cunnington JH. 2007. Seiridium cupressi is the common cause of cypress canker in south-eastern Australia. Australasian Plant Disease Notes 2 : 53-55.

Damm U, Crous PW, Fourie PH. 2008. A fissitunicate ascus mechanism in the Calosphaeriaceae, and novel species of Jattaea and Calosphaeria on Prunus wood. Persoonia 20: 39-52.

De Hoog GS, Gerrits van den Ende AHG. 1998. Molecular diagnostics of clinical strains of filamentous basidiomycetes. Mycoses 41: 183-189.

De Rulamort M. 1986. Remarques taxinomiques et nomenclaturales sur quelques micromycètes. Bulletin de la Societé Botanique du Centre-Ouest, nouvelle série 17: 191-192.

Eriksson OE. 1982. Notes on ascomycetes and coelomycetes from NW. Europe. Mycotaxon 15: 189-202.

Eriksson OE, Hawksworth DL. 1986. Notes on ascomycete systematics. Nos. 1-224. Systema Ascomycetum 5: 113-174.

Eriksson OE, Hawksworth DL. 1991. Notes on ascomycete systematics. Nos. 1252-1293. Systema Ascomycetum 10: 135-149.

Fabre JHC. 1883. Sphériacées du département de vaucluse. Annales des Sciences Naturelles, sexieme série, Botanique 15: 31-69, pl. 1-3.

Fuckel L. 1871 [1871-72]. Symbolae Mycologicae. Beiträge zur Kenntnis der Rheinischen Pilze. Erster Nachtrag. Jahrbücher des Nassauischen Vereins für Naturkunde 25-26: 287-346.

Fuckel L. 1874 [1873-74]. Symbolae Mycologicae. Zweiter Nachtrag. Jahrbücher des Nassauischen Vereins für Naturkunde 27-28: 1-99.

Guba EF. 1961. Monograph of Monochaetia and Pestalotia. Harvard University Press, Cambridge, Massachusetts.

Hall TA. 1999. BioEdit: a user-friendly biological sequence alignment editor and analysis program for Windows 95/98/NT. Nucleic Acids Symposium Series 41: 95-98. 
Harris RC. 1995. More Florida lichens, including the $10 \phi$ tour of the pyrenolichens. New York, R.C. Harris.

Hausknecht A, Greilhuber I, Jaklitsch W. 2003. Rezente Pilzfunde aus Osttirol. Österreichische Zeitschrift für Pilzkunde 12: 153-192.

Hernández-Restrepo M, Groenewald JZ, Crous PW. 2015. Taxonomic and phylogenetic re-evaluation of Microdochium, Monographella and Idriella. Persoonia 36: 57-82

Hodges CS, Barr ME. 1971. A new species of Pseudomassaria and its Beltraniella conidial state. Mycologia 63: 562-566.

Hughes SJ. 1958. Revisiones hyphomycetum aliquot cum appendice de nominibus rejiciendis. Canadian Journal of Botany 36: 727-836.

Jaklitsch WM. 2009. European species of Hypocrea - Part I. Studies in Mycology 63: 1-91.

Jaklitsch WM, Fournier J, Rogers JD, et al. 2014. Phylogenetic and taxonomic revision of Lopadostoma. Persoonia 32: 52-82.

Jaklitsch WM, Komon M, Kubicek CP, et al. 2005. Hypocrea voglmayrii sp. nov. from the Austrian Alps represents a new phylogenetic clade in Hypocrea/Trichoderma. Mycologia 97: 1365-1378.

Jaklitsch WM, Stadler M, Voglmayr H. 2012. Blue pigment in Hypocrea caerulescens sp. nov. and two additional new species in sect. Trichoderma. Mycologia 104: 925-941.

Jaklitsch WM, Voglmayr H. 2012. Phylogenetic relationships of five genera of Xylariales and Rosasphaeria gen. nov. (Hypocreales). Fungal Diversity 52: 75-98.

Kirk PM, Cannon PF, Minter DW, et al. 2008. Ainsworth \& Bisby's dictionary of the fungi, 10th edn. CABI, Wallingford.

Körber GW. 1865. Parerga lichenologica. Ergänzungen zum Systema lichenum Germaniae: 385-501.

Krokene P, Barnes I, Wingfield BD, et al. 2004. A PCR-RFLP based diagnostic technique to rapidly identify Seiridium species causing cypress canker. Mycologia 96: 1352-1354.

Liu YL, Whelen S, Hall BD. 1999. Phylogenetic relationships among ascomycetes: evidence from an RNA polymerase II subunit. Molecular Biology and Evolution 16: 1799-1808.

Lumbsch HT, Huhndorf SM. 2010. Myconet volume 14. Part one. Outline of ascomycota 2009. Part two. Notes on ascomycete systematics. Nos. 4751-5113. Fieldiana, Life and Earth Sciences 1-64.

Müller E, Von Arx JA. 1962. Die Gattungen der didymosporen Pyrenomyceten. Beiträge zur Kryptogamenflora der Schweiz 11, 2: 1-922.

Munk A. 1953. The system of the Pyrenomycetes. A contribution to a natural classification of the group Sphaeriales sensu Lindau. Dansk Botanisk Arkiv 15, 2: 1-163.

Munk A. 1957. Danish Pyrenomycetes. Dansk Botanisk Arkiv 17: 1-491.

Nag Raj TR. 1991. Updates on some species of Discosia. Canadian Journal of Botany 69: 1246-1250.

Nag Raj TR, Kendrick B. 1985. Ellurema gen. nov., with notes on Lepteutypa cisticola and Seiridium canariense. Sydowia 38: 178-193.

Nordén B, Jordal JB. 2014. Requienella seminuda, a corticolous ascomycete on Fraxinus excelsior new to Norway. Agarica 35: 29-34.

Otth G. 1868. Sechster Nachtrag zu dem in Nr. 15-23 enthaltenen Verzeichnisse schweizerischer Pilze. Mittheilungen der Naturforschenden Gesellschaft in Bern Nr. 654-683: 37-70.

Petrak F. 1923. Mykologische Notizen VI. Annales Mycologici 21: 182-335.

Petrak F. 1925. Mykologische Notizen VIII. Annales Mycologici 23: 1-143.

Petrak F. 1947. Kleine Beiträge zur Pilzflora von Tirol. Sydowia 1: 313-327.

Riethmüller A, Voglmayr H, Göker M, et al. 2002. Phylogenetic relationships of the downy mildews (Peronosporales) and related groups based on nuclear large subunit ribosomal DNA sequences. Mycologia 94: 834-849.

Saccardo PA. 1880. Fungi Gallici lecti a cl. viris P. Brunaud, Abb. Letendre, A. Malbranche, J. Therry vel editi in Mycotheca Gallica C. Roumeguéri. Series II. Michelia 2, 6: 39-135.

Saccardo PA. 1883. Sphaeriaceae, Pleophragmiae, Trematosphaeria. Sylloge Fungorum II: 118.
Scheinpflug H. 1958. Untersuchungen über die Gattung Didymosphaeria Fuck. und einige verwandte Gattungen. Berichte der Schweizerischen Botanischen Gesellschaft 68: 325-385.

Senanayake IC, Maharachchikumbura SSN, Hyde KD, et al. 2015. Towards unraveling relationships in Xylariomycetidae (Sordariomycetes). Fungal Diversity 73: 73-144.

Shirouzu T, Hirose D, Tokumasu S, et al. 2010. Host affinity and phylogenetic position of a new anamorphic fungus Beltraniella botryospora from living and fallen leaves of evergreen oaks. Fungal Diversity 43: 85-92.

Shoemaker RA, Leclair PM. 1975. Type studies of Massaria from the Wehmeyer collection. Canadian Journal of Botany 53: 1568-1598.

Shoemaker RA, Müller E. 1964. Generic correlations and concepts: Clathridium (= Griphosphaeria) and Seimatosporium (= Sporocadus). Canadian Journal of Botany 42: 403-410.

Shoemaker RA, Müller E. 1965. Types of the pyrenomycete genera Hymenopleella and Lepteutypa. Canadian Journal of Botany 43: 1457-1460.

Shoemaker RA, Müller E, Morgan-Jones C. 1966. Fuckel's Massaria marginata and Seiridium marginatum Nees ex Steudel. Canadian Journal of Botany 44: 247-254.

Silvestro D, Michalak I. 2012. raxmIGUI: a graphical front-end for RAxML. Organisms Diversity \& Evolution 12: 335-337.

Sowerby J. 1802. Coloured figures of English fungi or mushrooms 3, 25: plates 361-374. Sowerby, London.

Stamatakis E. 2006. RAxML-VI-HPC: maximum likelihood-based phylogenetic analyses with thousands of taxa and mixed models. Bioinformatics 22: $2688-2690$

Steyaert RL. 1949. Contribution à l'étude monographique de Pestalotia de Not. et Monochaetia Sacc. (Truncatella gen. nov. et Pestalotiopsis gen. nov.). Bulletin du Jardin Botanique de l'État à Bruxelles 19: 285-354.

Sutton BC. 1980. The Coelomycetes. Fungi imperfecti with pycnidia, acervuli and stromata. CMI, Kew.

Swart HJ. 1973. The fungus causing cypress canker. Transactions of the British Mycological Society 61: 71-82.

Swofford DL. 2002. PAUP* 4.0b10: phylogenetic analysis using parsimony ( ${ }^{*}$ and other methods). Sinauer Associates, Sunderland, Massachusetts.

Tanaka K, Endo M, Hirayama K, et al. 2011. Phylogeny of Discosia and Seimatosporium, and introduction of Adisciso and Immersidiscosia genera nova. Persoonia 26: 85-98.

Thiers B. 2015. Index Herbariorum: A global directory of public herbaria and associated staff. New York Botanical Garden's Virtual Herbarium. http:// sweetgum.nybg.org/ih/

Triebel D, Scholz P. 2015. IndExs - Index of Exsiccatae. Botanische Staatssammlung München. http://indexs.botanischestaatssammlung.de/.

Van der Aa JA. 1986. Revision of Keissleriella podocarpi Butin. Sydowia 39: $1-7$.

Vilgalys R, Hester M. 1990. Rapid genetic identification and mapping of enzymatically amplified ribosomal DNA from several Cryptococcus species. Journal of Bacteriology 172: 4238-4246.

Voglmayr H, Jaklitsch WM. 2008. Prosthecium species with Stegonsporium anamorphs on Acer. Mycological Research 112: 885-905.

Voglmayr H, Jaklitsch WM. 2011. Molecular data reveal high host specificity in the phylogenetically isolated genus Massaria (Ascomycota, Massariaceae). Fungal Diversity 46: 133-170.

Voglmayr H, Jaklitsch WM. 2014. Stilbosporaceae resurrected: generic reclassification and speciation. Persoonia 33: 61-82.

Voglmayr H, Yule C. 2006. Polyancora globosa gen. et sp. nov., an aeroaquatic fungus from Malaysian peat swamp forests. Mycological Research 110: 1242-1252.

Werle E, Schneider C, Renner M, et al. 1994. Convenient single-step, one tube purification of PCR products for direct sequencing. Nucleic Acids Research 22: 4354-4355.

Winter G. 1887. Ascomyceten: Gymnoasceen und Pyrenomyceten. Rabenhorst's Kryptogamen-Flora 2: 1-928. 